\title{
Article \\ Metagenomic Assessment of DNA Viral Diversity in Freshwater Sponges, Baikalospongia bacillifera
}

\author{
Tatyana V. Butina *(D), Ivan S. Petrushin (D), Igor V. Khanaev (D) and Yurij S. Bukin (D) \\ Limnological Institute, Siberian Branch of the Russian Academy of Sciences, 664033 Irkutsk, Russia; \\ ivan.kiel@gmail.com (I.S.P.); igkhan@lin.irk.ru (I.V.K.); bukinyura@mail.ru (Y.S.B.) \\ * Correspondence: tvbutina@mail.ru
}

check for updates

Citation: Butina, T.V.; Petrushin, I.S.; Khanaev, I.V.; Bukin, Y.S. Metagenomic Assessment of DNA Viral Diversity in Freshwater Sponges, Baikalospongia bacillifera. Microorganisms 2022, 10, 480. https://doi.org/10.3390/ microorganisms 10020480

Academic Editors: Veljo Kisand and Kasia Piwosz

Received: 28 December 2021 Accepted: 18 February 2022 Published: 21 February 2022

Publisher's Note: MDPI stays neutral with regard to jurisdictional claims in published maps and institutional affiliations.

Copyright: (C) 2022 by the authors. Licensee MDPI, Basel, Switzerland. This article is an open access article distributed under the terms and conditions of the Creative Commons Attribution (CC BY) license (https:// creativecommons.org/licenses/by/ $4.0 /)$.

\begin{abstract}
Sponges (type Porifera) are multicellular organisms that give shelter to a variety of microorganisms: fungi, algae, archaea, bacteria, and viruses. The studies concerning the composition of viral communities in sponges have appeared rather recently, and the diversity and role of viruses in sponge holobionts remain largely undisclosed. In this study, we assessed the diversity of DNA viruses in the associated community of the Baikal endemic sponge, Baikalospongia bacillifera, using a metagenomic approach, and compared the virome data from samples of sponges and Baikal water (control sample). Significant differences in terms of taxonomy, putative host range of identified scaffolds, and functional annotation of predicted viral proteins were revealed in viromes of sponge B. bacillifera and the Baikal water. This is the evidence in favor of specificity of viral communities in sponges. The diversity shift of viral communities in a diseased specimen, in comparison with a visually healthy sponge, probably reflects the changes in the composition of microbial communities in affected sponges. We identified many viral genes encoding the proteins with metabolic functions; therefore, viruses in Baikal sponges regulate the number and diversity of their associated community, and also take a part in the vital activity of the holobiont, and this is especially significant in the case of damage (or disease) of these organisms in unfavorable conditions. When comparing the Baikal viromes with similar datasets of marine sponge (Ianthella basta), in addition to significant differences in the taxonomic and functional composition of viral communities, we revealed common scaffolds/virotypes in the cross-assembly of reads, which may indicate the presence of some closely related sponge-specific viruses in marine and freshwater sponges.
\end{abstract}

Keywords: freshwater sponges; sponge holobionts; DNA viruses; viral diversity; metagenomics; viromes; gene prediction; functional analysis; Lake Baikal

\section{Introduction}

Sponges (type Porifera) are unusual representatives of Metazoa, striking with a variety of shapes, colors and structures. These invertebrates are widespread geographically, and some of them are endemic in several locations [1,2]. Sponges accommodate in their bodies various microorganisms such as heterotrophic bacteria, cyanobacteria, microscopic algae, archaea, dinoflagellates, fungi, and viruses [3]. Associated communities of sponges (holobionts) have unique properties - high diversity, abundance and biomass, contribution to primary production and nitrification through complex symbiosis, high chemical and physical adaptation, biomineralization, water filtration, etc.- -which determine the important role of sponges and make them an integral part of marine and freshwater ecosystems [4-6]. Extracts of various types of sponges have high antibacterial and antiviral activity against many serious pathogens of animals and humans, mainly due to the metabolites of associated symbionts [7]. This also makes the sponges especially valuable and attractive to researchers [8].

Currently, more than 8400 species of sponges are known around the world, and only a small number of them (about 238 sponge species) live in fresh waters; they include several 
families of the order Spongillida, the class Demospongiae [9]. Two families represent Baikal sponges: endemic Lubomirskiidae (includes 4 genera and 15 species) and cosmopolitan Spongillidae (3 genera and 5 species) [9-11]. The endemic species, Baikalospongia bacillifera, having a massive globular shape, is one of the most widespread in Lake Baikal [12].

Viruses are the least studied component of the sponge community, which is explained by the methodological difficulties in the investigation of the existing variety of viruses. However, new technologies and approaches such as next-generation sequencing and metagenomic analysis have become good alternatives to classical virological methods and useful aids in the study of uncultivated viruses [13], including the viral communities of sponge holobionts [14-16].

The first detection of virus-like particles (VLPs) in marine sponges, which were similar in morphology to adenoviruses, dates back to 1978 [17]. Later, picornaviruses and mimiviruses were detected in some sponges $[18,19]$. Recently, a large number and variety of viruses in associated communities of sponges have been discovered during a mass electron microscopic (TEM) study [20] and confirmed by metagenomic sequencing of viral communities from various marine sponge species. Such virome studies were carried out for sponges inhabiting the Great Barrier Reef [21,22], the area of the Southwestern Atlantic Ocean (Arraial do Cabo Bay, South-Eastern Brazil) [23], and Lake Baikal [24,25]. Some studies were focused on the study of RNA viruses in sponges [26,27]. In general, various virome sequences related to viruses from more than 20 families, as well as many unclassified and unidentified viruses, were revealed in different marine and freshwater sponges [14-16,25]. The bulk of the sponge-associated viruses are DNA viruses - both single-stranded (ssDNA) and double-stranded (dsDNA) ones [21]. A significant host species specificity for viruses infecting sponge holobionts was shown both at the taxonomic and functional levels [14,22,23]. Thus, studies concerning the composition of viral communities in sponges have appeared rather recently $[3,28]$, and many questions regarding the diversity and participation of viruses in the functioning of the sponge holobiont remain largely undisclosed. To the best of our knowledge, the viral communities of freshwater sponges (except for Baikal ones) have not yet been studied.

Viruses most likely play a significant role in the associated community of sponges inhabiting Lake Baikal and affect the ecology and the general state of the lake as a whole. Lake Baikal, like other freshwater bodies, experiences a certain level of anthropogenic pressure; global climate changes also affect its condition. In recent years, anomalous phenomena have occurred on Lake Baikal, which were most obvious in coastal recreational areas of the lake. Changes are observed in the composition of benthic communities, among them: the rich development of filamentous algae and cyanobacteria, overgrowth of macrophytes with ciliates, and massive damage and death of the sponges [12,29-32]. The problem of sponge disease concerns not only Baikal sponges; cases of their visible changes and damage were described all over the world [33-35]. Understanding the cause of sponge diseases is still insufficient. Most often, there are significant changes in the quantitative and qualitative composition of microorganisms in diseased sponges [33,35-40]. Sometimes, the pathogenic bacteria are present, and they probably participate in epizootics [41]. For marine sponges, the root cause can be an increase in water temperature [42]. The generally accepted opinion is that sponge diseases (or syndromes) may be due to the disruption of complex interactions within the holobiont under environmental stress, resulting in opportunistic or polymicrobial infections $[34,35,42]$. The role of viruses in sponge disease is largely unexplored. This topic requires special attention and great efforts of researchers.

The aim of this study was to assess the diversity of DNA viruses in the associated community of the Baikal endemic sponge, Baikalospongia bacillifera, (visually healthy and damaged) using a metagenomic approach (the data reported in [25]), and to compare the virome data from the samples of sponges and Baikal water (control sample, [43]). 


\section{Materials and Methods}

\subsection{Sampling and Sample Processing}

The $B$. bacillifera sponges were sampled in sterile tubes in the southern basin of Lake Baikal, near Bolshiye Koty $\left(51^{\circ} 54^{\prime} 07.5^{\prime \prime} \mathrm{N}, 105^{\circ} 06^{\prime} 12.0^{\prime \prime} \mathrm{E}\right)$, at depths of about $16 \mathrm{~m}$ in May 2018 by divers using lightweight diving equipment. The two specimens of B. bacillifera of $5-7 \mathrm{~cm}^{3}$ in volume were collected and used in this study: one looked healthy (Sv2478.2h), and another had necrosis lesions (Sv2475.1d) (Figure 1). Sponge samples were processed, and concentrates of VLPs were obtained as described in [25].

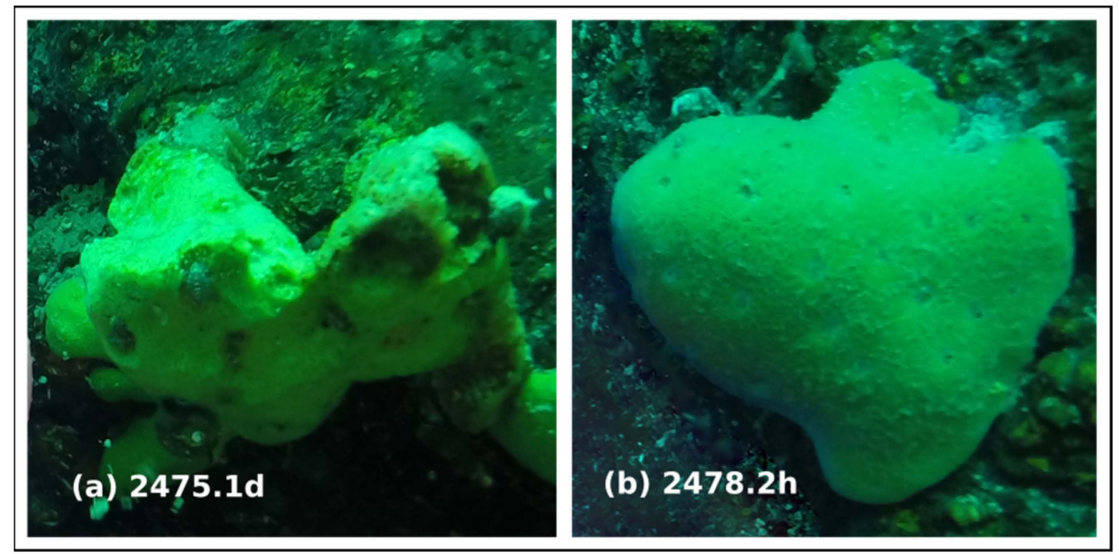

Figure 1. The sponges Baikalospongia bacillifera, (a) diseased and (b) healthy individuals, used in our study of DNA viral communities.

At the same time, the control near-bottom water samples were also taken from the sponge sampling site at depths of 10,12, and $15 \mathrm{~m}$. The sampling was carried out by a diver using a bathometer. The water samples were filtered through $0.2 \mathrm{~mm}$ nitrocellulose filters (Sartorius, Goettingen, Germany) and combined (sample Lbw.4g). The filtrate containing virus-like particles was concentrated as described in [43].

Detailed description of sample processing (of the sponges and water), VLPs and viral DNA extraction, further sequencing, and bioinformatics analysis can be found in the Supplementary Materials (Supplementary File S1).

\subsection{Library Preparation and Sequencing}

The preparation and sequencing of DNA libraries were performed in The Center of Shared Scientific Equipment "Persistence of Microorganisms" of the Institute for Cellular and Intracellular Symbiosis, Ural Branch of the Russian Academy of Sciences, Orenburg, Russia. Sequencing of the libraries was conducted on the MiSeq platform (Illumina, San Diego, CA, USA) using MiSeq Reagent Kit v3 (2 × 300cycles).

Unprocessed virome reads for samples Sv2475.1d, Sv2478.2h, and Lbw.4g were submitted to the National Center for Biotechnology Information (NCBI), Sequence Read Archive (SRA) database (BioProject PRJNA577390, BioSamples SAMN13025046, SAMN13025227, and SAMN16330433) [25,43]. The direct URL to the data is as follows: https: / Www.ncbi. nlm.nih.gov / sra/PRJNA577390 (accessed on 20 December 2021).

\subsection{Initial Shotgun Metagenomic Data on DNA Viruses in Marine Sponges and Water Samples}

For comparative analysis, we also used the NCBI SRA datasets on marine sponge Iantella basta (Pallas, 1766) (class Demospongiae) and ocean water viromes (Great Barrier Reef (GBR), Davies Reef, sampled in January 2014; [22]) sequenced using the same library preparation and sequencing techniques as in our study (the Illumina MiSeq platform). Similar to our data, in the study of the sponges I. basta, diseased and healthy specimens were sampled, and at the same time, a control water sample was taken at the sponge sampling site, as follows from the description of the marine samples (Table 1). 
Table 1. Description of virome datasets used for analysis.

\begin{tabular}{|c|c|c|c|c|c|c|c|}
\hline $\begin{array}{l}\text { Dataset } \\
\text { Name }\end{array}$ & $\begin{array}{c}\text { Sample } \\
\text { Description }\end{array}$ & $\begin{array}{l}\text { Geographic } \\
\text { Location }\end{array}$ & $\begin{array}{l}\text { Latitude and } \\
\text { Longitude }\end{array}$ & Data & BioProject & Experiments & Reference $^{1}$ \\
\hline GBR.sw & Seawater control & $\begin{array}{l}\text { Australia: } \\
\text { GBR, Davies } \\
\text { Reef }\end{array}$ & 18.83 S 147.63 E & 2014-10 & PRJNA388297 & $\begin{array}{l}\text { SRX2883300, } \\
\text { SRX2883301, } \\
\text { SRX2883298 }\end{array}$ & $\begin{array}{l}- \\
- \\
-\end{array}$ \\
\hline I.basta.h & $\begin{array}{l}\text { Ianthella basta, } \\
\text { disease-free } \\
\text { sponge }\end{array}$ & $\begin{array}{c}\text { Australia: } \\
\text { GBR, Davies } \\
\text { Reef }\end{array}$ & 18.83 S 147.63 E & 2014-10 & PRJNA388007 & $\begin{array}{l}\text { SRX2864027, } \\
\text { SRX2864026, } \\
\text { SRX2864019 }\end{array}$ & $\begin{array}{c}- \\
{[22]} \\
{[22]}\end{array}$ \\
\hline I.basta.nd & $\begin{array}{c}\text { Ianthella basta, } \\
\text { non-diseased } \\
\text { region of diseased } \\
\text { sponge }\end{array}$ & $\begin{array}{c}\text { Australia: } \\
\text { GBR, Davies } \\
\text { Reef }\end{array}$ & 18.83 S 147.63 E & 2014-10 & PRJNA388007 & $\begin{array}{l}\text { SRX2864023, } \\
\text { SRX2864022, } \\
\text { SRX2864016 }\end{array}$ & $\begin{array}{l}{[22]} \\
{[22]} \\
{[22]}\end{array}$ \\
\hline I.basta.d & $\begin{array}{c}\text { Ianthella basta, } \\
\text { disease lesion of } \\
\text { diseased sponge }\end{array}$ & $\begin{array}{l}\text { Australia: } \\
\text { GBR, Davies } \\
\text { Reef }\end{array}$ & 18.83 S 147.63 E & 2014-10 & PRJNA388007 & $\begin{array}{l}\text { SRX2864021, } \\
\text { SRX2864020, } \\
\text { SRX2864018 }\end{array}$ & $\begin{array}{l}- \\
- \\
-\end{array}$ \\
\hline I.basta.md & $\begin{array}{l}\text { Ianthella basta, } \\
\text { lesion interface of } \\
\text { diseased sponge }\end{array}$ & $\begin{array}{c}\text { Australia: } \\
\text { GBR, Davies } \\
\text { Reef }\end{array}$ & 18.83 S 147.63 E & 2014-10 & PRJNA388007 & $\begin{array}{l}\text { SRX2864025, } \\
\text { SRX2864024, } \\
\text { SRX2864017 }\end{array}$ & $\begin{array}{l}- \\
- \\
-\end{array}$ \\
\hline Sv2475.1d & $\begin{array}{c}\text { Baikalospongia } \\
\text { bacillifera, diseased } \\
\text { sponge }\end{array}$ & $\begin{array}{c}\text { Russia: Lake } \\
\text { Baikal }\end{array}$ & $51.90 \mathrm{~N} 105.10 \mathrm{E}$ & 2018-06 & PRJNA577390 & SRX6994059 & This study \\
\hline Sv2478.2h & $\begin{array}{l}\text { Baikalospongia } \\
\text { bacillifera, } \\
\text { disease-free } \\
\text { sponge }\end{array}$ & $\begin{array}{c}\text { Russia: Lake } \\
\text { Baikal }\end{array}$ & $51.90 \mathrm{~N} 105.10 \mathrm{E}$ & 2018-06 & PRJNA577390 & SRX6994055 & This study \\
\hline LBw.4g & $\begin{array}{l}\text { Lake Baikal water } \\
\text { control }\end{array}$ & $\begin{array}{l}\text { Russia: Lake } \\
\text { Baikal }\end{array}$ & 51.90 N $105.10 \mathrm{E}$ & 2018-06 & PRJNA577390 & SRX9228319 & This study \\
\hline
\end{tabular}

${ }^{1}$ Unpublished datasets are marked with "-".

The paired reads of marine viromes were combined into one FASTQ dataset together with the Baikal ones; then joint primary processing of paired reads was carried out as described below. All data were used for a hybrid metagenomic assembly (cross-assembly) in one round of data analysis.

\subsection{Primary Processing of Virome Reads}

The quality visualization of the virome datasets (paired reads) was carried out using the FASTQC program. Trimming of reads by the quality was carried out with the Trimmomatic V 0.39 program [44].

\subsection{Assembly of Virome Reads, Identification, and Taxonomic Assignment of Viral Scaffolds}

The assembly of viral reads and further taxonomic identification of viral scaffolds were carried out as reported before in the study of water samples from different areas of Lake Baikal [45]. Briefly, the SPAdes 3.13.1 (metaSPAdes) [46] was used for the de novo cross-assembly of datasets (marine and freshwater, Table 1). The scaffolds with coverage more than 5 and a length of $\geq 5000 \mathrm{bp}$ were used for further analysis. The VirSorter tool [47] was used for identification of the viral scaffolds and open reading frames (ORFs) in them. Taxonomic identification for the viral scaffolds was carried out by comparisons of scaffolds sequences with the NCBI RefSeq complete viral genome and viral proteome database [48] with BLASTp and BLASTn algorithms [49]. A virus taxon from NCBI RefSeq with the highest proportion of coverage in alignments of the nucleotide sequences was chosen as the scaffold virotype identifier.

The Burrows-Wheeler Aligner (BWA) software [50] was used to map paired-end reads on scaffolds and calculate the total coverage of viral scaffolds in the assembly and coverage 
of scaffolds by reads from each sample. The count table of viral scaffold representation in the analyzed samples normalized to the length of scaffolds was constructed.

\subsection{Statistical Analysis of Taxonomic Diversity}

The potential (underestimated) number of virus scaffolds and virotypes (species richness) in communities was evaluated using Chao1 [51] and ACE [52] indices. Shannon and Simpson indices [53] of biodiversity were also calculated (Table 2) for virus scaffolds and virotypes. The taxonomic composition similarity of the samples (similarity in virus scaffold count table per samples) was visualized using hierarchical cluster analysis with bootstrap support calculation of clustering in the "pvclust" [54] package for the R and the nonmetric multidimensional scaling (NMDS) ordination method. Biodiversity analysis and NMDS were carried out in the "vegan" package for the R [55].

Dominant scaffolds and virotypes in Baikal and marine samples were visualized with the heat map using the "gplots" [56] package for the R. Columns (samples) in the heat map were clustered and grouped in similarity order (i.e., Bray-Curtis distance metric and the complete-link clustering method).

The significance of the difference between the samples in counts of virotype reads was assessed using the chi-square test for independence with Bonferroni $p$-value correction.

\subsection{Functional Assignment of Viral Communities}

Functional assignment of predicted viral proteins (ORFs) was carried out in three different ways: (1) matched ORFs with the UniProtKB/Swiss-Prot database [57] by the BLASTp algorithm; (2) matched ORFs with functional motifs of proteins in the Pfam database [58] using an online resource (https://www.ebi.ac.uk/Tools/pfa/pfamscan/, accessed on 20 September 2021) [59]; (3) matched ORFs with functional motifs of proteins in the KOfam database using an online resource (https:/ / www.genome.jp/tools/kofamkoala/, accessed on 20 September 2021) [60]. All three results were transformed to KO (KEGG pathway classification functional groups) anthologies [61] and processed in the "KEGGREST" package [62] for the R. The count of the predicted viral proteins in samples was transformed into counts of the KEGG pathway classification groups that were normalized for the average number of hits on the viral proteins in each sample. The counts of AMGs (auxiliary metabolic genes) viral proteins in different samples were visualized with a heat map generated using the "gplots" package [56] for the R.

\subsection{Viral Hosts Prediction}

Host prediction for the set of viral scaffolds was carried out by the method as described previously [45], basing on taxonomic identification of predicted viral scaffolds and the Virus-Host database [63]. The count of the viral scaffolds was transformed into tables representing DNA viruses (virotypes) that infect a certain host species and analyzed in the NMDS scatter plot of viral scaffolds count table comparisons.

\subsection{Bacterial Defense Mechanisms against Viruses}

The genomic assemblies of two bacterial strains, Flavobacterium sp. SLB02 and Janthinobacterium sp. SLB01, isolated from the diseased Baikal sponge Lubomirskia baikalensis has been published previously [64]. In our study, we analyzed whether these strains have any antiviral defense mechanisms. To search for defense mechanisms, we analyzed bacterial genomes using the Prokaryotic Antiviral Defense LOCator (PADLOC) [65] and CRISPRCasFinder [66] algorithms, and the numbers of CRISPR arrays were detected. Spacers' sequences were aligned with viral scaffolds from our study using the BLASTn-short algorithm [49], as recommended in [67]. 
Table 2. General statistics and viral diversity indices for the datasets used in the study.

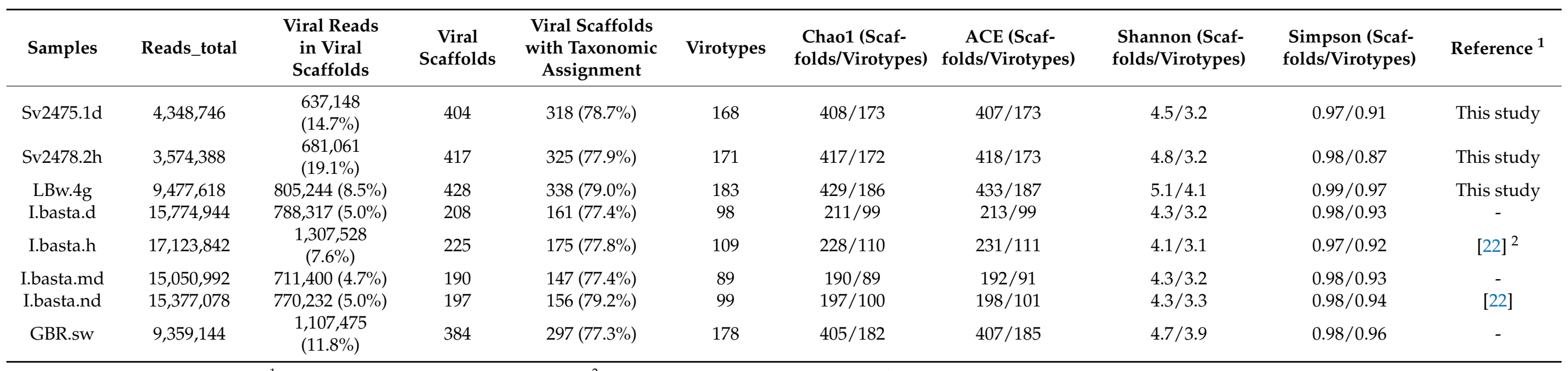

${ }^{1}$ Unpublished datasets are marked with "-". ${ }^{2}$ Partially published dataset (see Table 1 for details). 


\section{Results}

\subsection{Taxonomic Affiliation of Viral Sequences in Baikal Samples}

After processing and filtering the raw reads, we obtained the three sets of Baikal virome data, from 3.6 to 9.5 million paired reads each (Table 2). The proportions of viral reads in our datasets ranged from $15.3 \%$ to $28.8 \%$; those of bacterial and eukaryotic sequences did not exceed $15 \%$ and $2.4 \%$, respectively, while a significant part of the reads was not identified (up to 73.3\%) (Supplementary Figure S1). The percentage of viral reads was found to be comparable with that of other virome studies with viral particle enrichment (or even higher, such as compared with the marine samples we used in this study, Table 1).

In total, 2916 scaffolds with length $\geq 5000 \mathrm{bp}$ and coverage $\geq 5$ were assembled using the metaSPAdes software together with marine virome reads; 673 scaffolds were identified as viral by the VirSorter program, more than 400 scaffolds consisted of Baikal reads. The total numbers of Baikal reads belonging to identified viral scaffolds were 637,148 (14.7\% of the total reads, sample B. bacillifera_Sv2475.1d), 681,061 (19.1\%, sample B. bacillifera_Sv2478.2h), and 805,244 (8.5\%, sample Baikal water_Lbw.4g). For the marine sponge viromes [22] and the ocean water sample (Table 1), the percentages of viral reads were $4.7 \%$ to $11.8 \%$ (Table 2 ).

Taxonomic affiliation (as similar viral genome or virotype) was assigned for 318 to $338(78.7 \%$ to $79.0 \%$ ) scaffolds (Table 2; Supplementary Table S6). In total, more than 168 virotypes were identified in the samples of the $B$. bacillifera sponges and surrounding water. The largest number of virotypes (183) was found in the Baikal water sample, and the smallest number (163) was found in the diseased sponge (Sv2475.1d). In general, the indices of diversity and species richness of the Baikal viral communities were high and comparable with or higher than those for marine samples (Table 2). The greatest variety of viruses was observed in control water samples with both fresh and sea water.

The identified virotypes belonged to 11 families of DNA-containing viruses (Figure 2a; Supplementary Table S1). The most numerous of them were the tailed bacteriophages of the families Siphoviridae (35.8\% to $45.2 \%$ of viral reads), Podoviridae (20.2\% to $30.6 \%$ ), and Myoviridae (6.6\% to $12.1 \%$ ). Additionally, bacteriophages of the families Herelleviridae and Ackermannviridae were also detected but in small numbers (less than $0.3 \%$ ). Virophages of the family Lavidaviridae were among the dominant ones (3.1\% to 6.3\%). These satellite viruses infect protozoa but only in the case of co-infection with other viruses, members of the family Mimiviridae [68]. The mimiviruses also presented a small fraction of viral scaffolds. Among the others, there were the viral families, known representatives of which infect microalgae (Phycodnaviridae), archaea (Bicaudaviridae), and arthropods, including crustaceans (Baculoviridae, Poxviridae) and vertebrates (Poxviridae). Notably, a large number of sequences identified as viral using the VirSorter program had no analogues in the NCBI database (14.5-19.0\% of unknown reads) (Figure 2a; Supplementary Table S1).

The dominant and other families were similar for all Baikal samples, but their proportions differed. For example, the Siphoviridae prevailed in the Baikal water sample, but the Podoviridae, as well as virophages of the Lavidaviridae family, were more represented in the sponge samples (Figure 2a; Supplementary Table S1). The differences in the representation of viral families and virotypes in the Baikal samples are summarized in Table 3. 

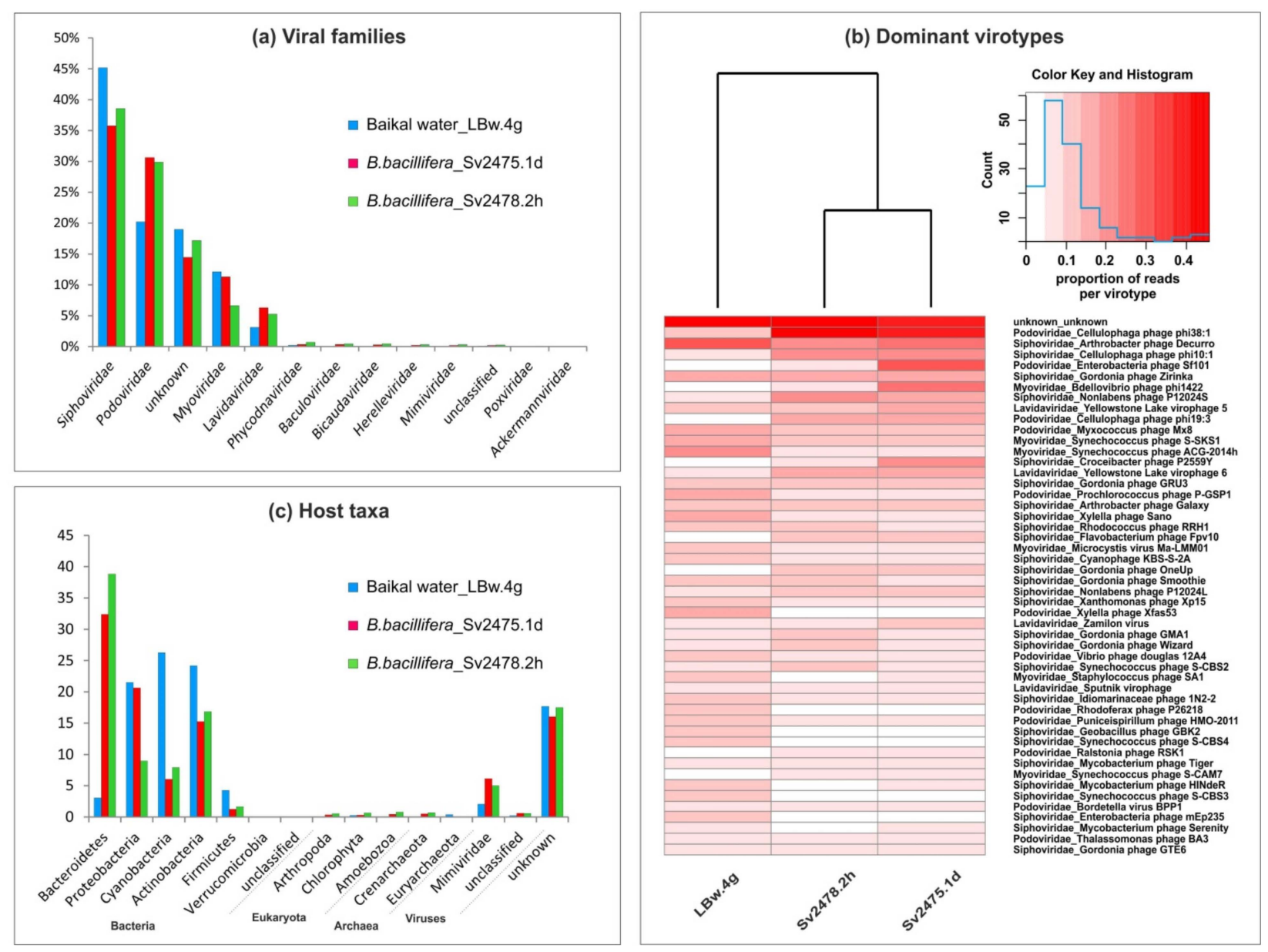

Figure 2. The taxonomic identification of viral sequences and putative hosts for revealed virotypes in the Baikal viromes: (a) the percentages of viral families; (b) heat maps demonstrating the distribution of 50 dominant virotypes in the samples (clustering was based on the Bray-Curtis distances); (c) the predicted viral hosts.

Table 3. The main differences between diseased and healthy specimens of Baikal sponges.

\begin{tabular}{|c|c|c|c|c|}
\hline \multirow{2}{*}{$\begin{array}{l}\text { Over-Represented } \\
\text { Viral Taxa or } \\
\text { Functions }\end{array}$} & \multicolumn{2}{|c|}{ Baikal Water vs. Sponges } & \multicolumn{2}{|c|}{ Healthy vs. Diseased } \\
\hline & LBw.4 g & B. bacillifera & $2478.2 \mathrm{~h}$ & $2475.1 \mathrm{~d}$ \\
\hline Families & Siphoviridae & $\begin{array}{l}\text { Podoviridae, } \\
\text { Lavidaviridae, } \\
\text { Mimiviridae, } \\
\text { Baculoviridae, } \\
\text { Bicaudaviridae, } \\
\text { Herelleviridae }\end{array}$ & $\begin{array}{l}\text { Siphoviridae, } \\
\text { Phycodnaviridae, } \\
\text { Mimiviridae, } \\
\text { Baculoviridae, } \\
\text { Bicaudaviridae, } \\
\text { Herelleviridae }\end{array}$ & Myoviridae \\
\hline Virotypes & $\begin{array}{c}\text { Arthrobacter phage } \\
\text { Decurro, Synechococcus } \\
\text { phages S-SKS1 and } \\
\text { ACG-2014h, } \\
\text { Prochlorococcus phage } \\
\text { P-GSP1, Xylella phages } \\
\text { Sano and Xfas53 }\end{array}$ & $\begin{array}{c}\text { Cellulophaga phages, } \\
\text { (phi38:1, phi10:1, and } \\
\text { phi19:3), Yellowstone lake } \\
\text { virophage } 6 \text { and others }\end{array}$ & $\begin{array}{c}\text { Nonlabens phage } \\
\text { P12024S, Gordonia } \\
\text { phages (GMA1, Wizard, } \\
\text { etc.), Synechococcus } \\
\text { phage S-CBS2 }\end{array}$ & $\begin{array}{c}\text { Enterobacteria phage } \\
\text { Sf101, Bdellovibrio phage } \\
\text { phi1422, Croceibacter } \\
\text { phage P2559Y }\end{array}$ \\
\hline
\end{tabular}


Table 3. Cont.

\begin{tabular}{|c|c|c|c|c|}
\hline \multirow{2}{*}{$\begin{array}{l}\text { Over-Represented } \\
\text { Viral Taxa or } \\
\text { Functions }\end{array}$} & \multicolumn{2}{|c|}{ Baikal Water vs. Sponges } & \multicolumn{2}{|c|}{ Healthy vs. Diseased } \\
\hline & LBw.4 g & B. bacillifera & $2478.2 \mathrm{~h}$ & $2475.1 \mathrm{~d}$ \\
\hline Putative hosts & $\begin{array}{l}\text { Cyanobacteria, } \\
\text { Actinobacteria, } \\
\text { Firmicutes, } \\
\text { Euryarchaeota }\end{array}$ & $\begin{array}{l}\text { Bacteroidetes, } \\
\text { Crenarchaeota, } \\
\text { Amoebozoa, } \\
\text { Arthropoda, } \\
\text { Mimiviridae }\end{array}$ & $\begin{array}{l}\text { Chlorophyta, } \\
\text { Amoebozoa, }\end{array}$ & Proteobacteria \\
\hline $\begin{array}{l}\text { Functional categories } \\
\text { (except "Metabolism") }\end{array}$ & $\begin{array}{c}\text { 'Replication and } \\
\text { repair', 'Environmental } \\
\text { adaptation', 'Digestive } \\
\text { system' }\end{array}$ & $\begin{array}{c}\text { 'Folding, sorting and } \\
\text { degradation', } \\
\text { 'Translation', 'Cell } \\
\text { growth and death', } \\
\text { 'Aging' }\end{array}$ & 'Signal transduction' & 'Cell growth and death' \\
\hline Metabolic functions & $\begin{array}{l}\text { 'Metabolism of } \\
\text { terpenoids and } \\
\text { polyketides', 'Glycan } \\
\text { biosynthesis and } \\
\text { metabolism', } \\
\text { 'Carbohydrate } \\
\text { metabolism' }\end{array}$ & $\begin{array}{c}\text { 'Nucleotide } \\
\text { metabolism', } \\
\text { 'Xenobiotics } \\
\text { biodegradation and } \\
\text { metabolism' }\end{array}$ & $\begin{array}{l}\text { Almost all (except } \\
\text { 'Amino acid } \\
\text { metabolism'), 'Folate } \\
\text { biosynthesis' }\end{array}$ & $\begin{array}{c}\text { 'Amino acid } \\
\text { metabolism', } \\
\text { 'Riboflavin metabolism' }\end{array}$ \\
\hline
\end{tabular}

\subsection{Virotypes Diversity}

Differences between the freshwater samples are clearly observed during the comparison of the sets of the identified virotypes (Figure 2b; Supplementary Table S2). In the Baikal water sample, the Arthrobacter phage Decurro, the Synechococcus phages ACG-2014h, S-SKS1, and other cyanophages, Xylella phages Sano and Xfas53, were the most abundant. The sponge samples differed from the control water sample by a high content of sequences that corresponded to genomes of the Cellulophaga phages phi10:1, phi38:1, and phi19:3, Yellowstone lake virophage 6, and others (Figure 2b; Supplementary Table S6). In the sample of a diseased sponge, compared with others, there was higher content of sequences similar to the Enterobacteria phage Sf101, Bdellovibrio phage phi1422, and Croceibacter phage P2559Y. In the sample of a healthy sponge, the Nonlabens phage P12024S, Gordonia phages (GMA1, Wizard, etc.), and Synechococcus phage S-CBS2 prevailed.

Among eukaryotic viruses, Melanoplus sanguinipes entomopoxvirus, the Yellowstone lake phycodnavirus 1 and 2, Paramecium bursaria Chlorella virus 1, and Bathycoccus sp. RCC1105 virus BpV1 from the family Phycodnaviridae were detected in the Baikal sponges and nearbottom water; the scaffolds similar to the virotypes Paramecium bursaria Chlorella virus 1 and Yellowstone lake phycodnavirus 1 were mainly covered with reads from sponge samples, but Yellowstone lake phycodnavirus 2 was covered with reads from a control water sample (Supplementary Table S6).

\subsection{Putative Range of Viral Hosts}

We defined the potential host range for the detected Baikal viruses (virotypes) based on known hosts for the identified virotypes according to the Virus-Host database [63]. Using this approach, the putative hosts were determined for a wide range of viruses (bacteriophages and others). Unfortunately, other available resources and software predict mainly prokaryotic hosts. In total, six bacterial, two archaeal, and four eukaryotic phyla, as well as one viral family (the Mimiviridae affected by virophages in case of coinfection of protists) were identified (Figure 2c; Supplementary Tables S3 and S7). Among the bacterial taxa, the Bacteroidetes, Actinobacteria, Proteobacteria, and Cyanobacteria prevailed (up to $21.5-38.8 \%$ in the samples, with the mean value of more than $13.4 \%$ in terms of the number of reads), while Firmicutes and Verrucomicrobia did not exceed $4.3 \%$ and $0.02 \%$ of the reads, respectively (the mean value less $2.4 \%$ and $0.01 \%$ of the reads) (Supplementary Table S3). A significant difference in the range of viral hosts was observed between the 
samples. For example, the Bacteroidetes were much more abundant (about an order of magnitude) in sponge samples than in the water sample (32.4\% to $38.8 \%$ vs. $3.1 \%)$, while the Cyanobacteria and Firmicutes predominated in Baikal water $(26.3 \%$ vs. $6.0 \%$ to $8.0 \%$ and $4.3 \%$ vs. $1.3 \%$ to $1.7 \%$, respectively) (Supplementary Tables S3 and S7). Predicted eukaryotic hosts were generally few (less than $0.8 \%$ ); among them, the Amoebozoa and Chlorophyta were the most represented.

Analysis of the bacteria Janthinobacterium sp. strain SLB01 and Flavobacterium sp. Strain SLB02 from the Baikal sponge Lubomirskia baikalensis [64] revealed seven variants of CRISPR-Cas spacers (one in SLB01 and six in SLB02) and five other types of antiphage defense systems, including recently discovered [65,69] (dGTPase, Zorya_type I, Septu_type I, Gabija, Cbass_type III) (Supplementary Tables S4 and S5, File S3). The 14 matches of CRISPR-Cas spacers from Strain SLB02 and SLB01 were found with 13 different viral scaffolds from the sponge B. bacillifera (Supplementary File S4). Taxonomically, these scaffolds belong to 12 different virotypes (viruses of bacteria, cyanobacteria, or eukaryotic algae). The length of complete matches between spacer and the viral genome ranges from 7 to 15 nucleotides, which is sufficient to counteract the virus. This analysis suggests that some similar bacteria and viruses associate with the sponges L. baikalensis and B. bacillifera (healthy or diseased).

\subsection{Functional Analysis of Baikal Viromes}

We carried out a functional analysis of viromes and identified 5 main and 29 secondary categories of proteins according to the KEGG Orthology database (Figure 3; Supplementary Table S8). A total of 15,453 open reading frames were predicted in viral scaffolds using the VirSorter program, among which 2629 proteins (proteins with KO_ID) were identified using the Pfam, KOfam and UniProt databases (2456, 514, and 402, respectively). Most of them (1245) were proteins with an undefined functional category (unclassified or "no type" in Supplementary Table S8); they were not considered in further analysis.

The largest number of identified proteins in B. bacillifera sponge viromes belonged to the "Metabolism" and "Genetic Information Processing" main categories (Figure 3). In the first category, the largest number of reads in both sponges (healthy and diseased) belonged to proteins involved in the metabolism of nucleotides, cofactors and vitamins. Additionally, the proteins of amino acid metabolism predominated in the diseased sponge. The proteins of the 'Replication and repair' prevailed in the Baikal water sample (LBw.4g), but the 'Folding, sorting and degradation' and 'Translation' (of the main category "Genetic Information Processing"), as well as the 'Cell growth and death' ("Cellular Processes"), were the most abundant in sponges. In general, the functional profile in the two sponge samples was similar, apart from the proteins of the secondary category 'Amino acid metabolism' (much more in diseased sponges) and the 'Cell growth and death' (also more represented in the diseased sponge). The proportions of reads in some other functional groups also differed but insignificantly.

In the "Metabolism" category, among the most numerous proteins in terms of diversity and proportion of reads, in addition to proteins involved in the metabolism of nucleotides and amino acids, there were enzymes participating in the metabolism of cofactors and vitamins (Figures 3 and 4). The proteins of folate biosynthesis (thymidylate synthase, 2-amino-4hydroxy-6-hydroxymethyldihydropteridine diphosphokinase, and others) were the most numerous (Supplementary Table S8). Conversely, the proteins of 'Riboflavin metabolism' (riboflavin kinase, archaea type) predominated in the diseased sponge. In this secondary category ('Metabolism of cofactors and vitamins'), we also identified the proteins involved in the metabolism of biotin, nicotinate and nicotinamide, thiamine, porphyrin, and chlorophyll. In terms of the number of reads, the most numerous were also the proteins of the biosynthesis and metabolism of glycans. Among the enzymes of biosynthesis of secondary metabolites, we identified those involved in streptomycin, acarbose and validamycin, and staurosporine biosynthesis (Supplementary Table S8). The presence and expression of auxiliary metabolic genes (AMGs) for synthesis of vitamins, antimicrobials, and toxin protection in marine 
sponges have been reported previously [14,15]. In general, in the diseased sponge, the proportion of enzymes of all metabolic categories, except for amino acid metabolism, was slightly lower than in the healthy one (Figure 3; Supplementary Table S8).

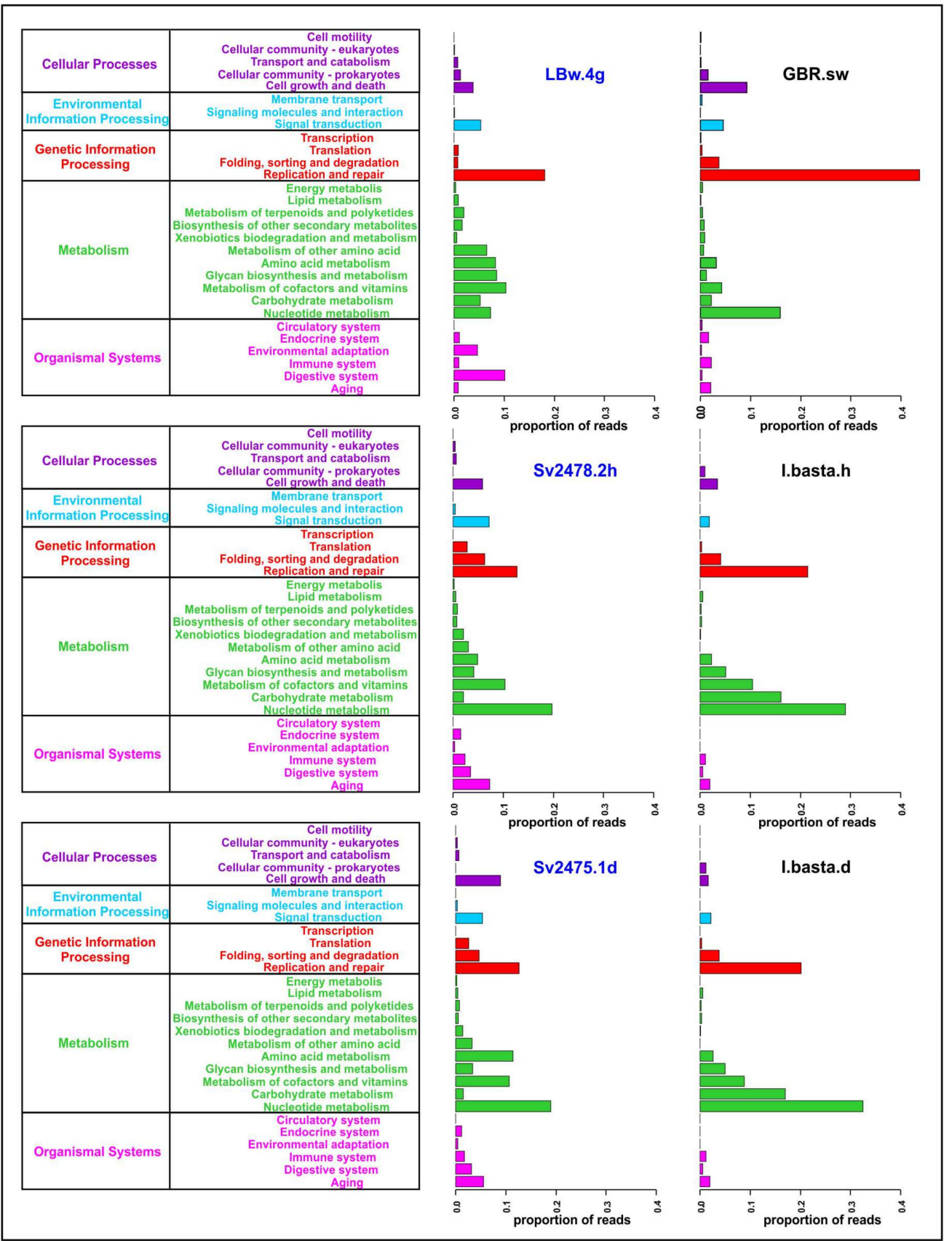

Figure 3. General functional annotation of the sponge and water viromes analyzed in the study (the main and secondary functional categories are indicated, according to the KEGG Orthology). The Baikal samples are highlighted in blue. 


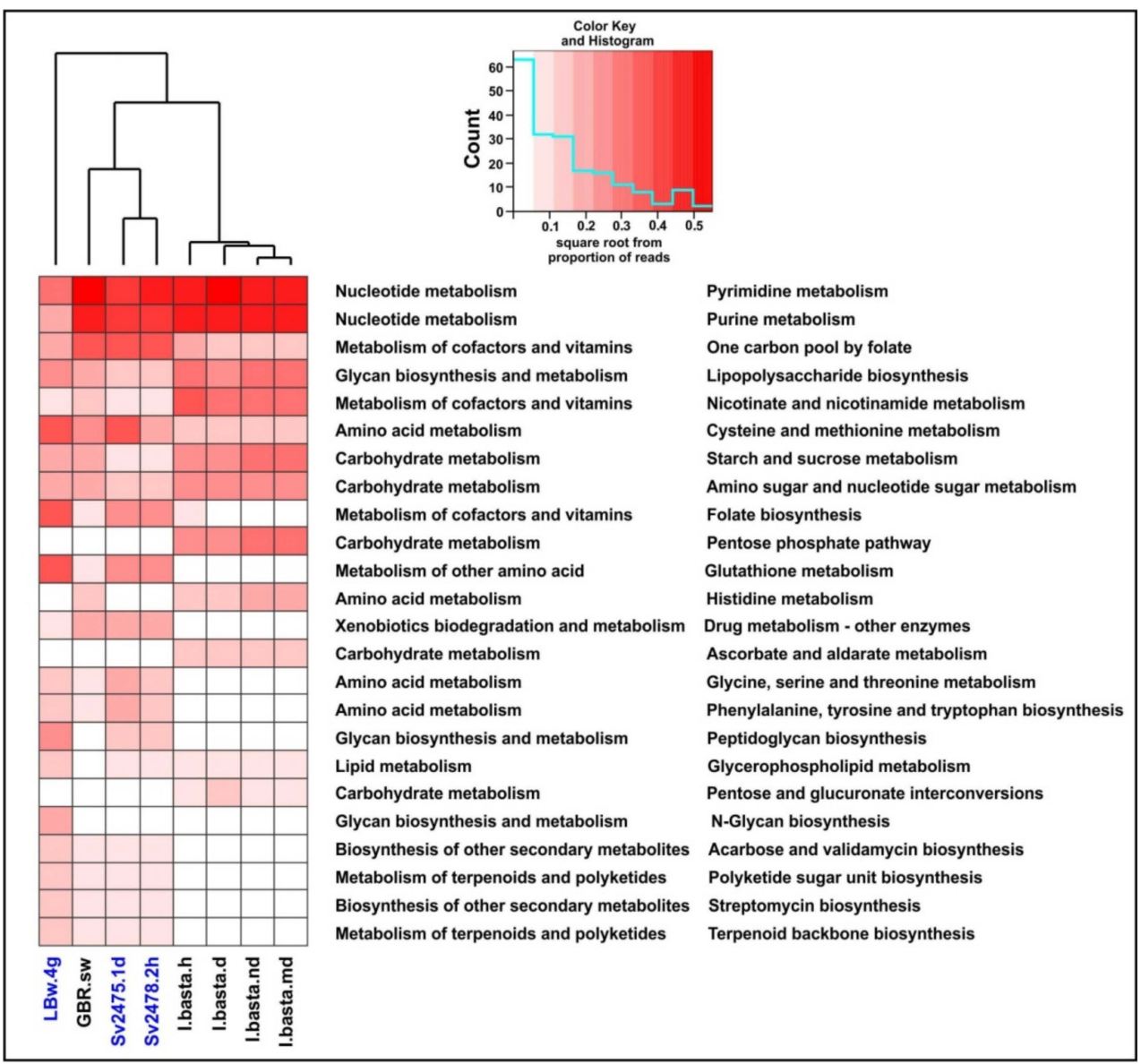

Figure 4. Dominant metabolic functions defined in marine and freshwater virome datasets. The Baikal samples are highlighted in blue.

\subsection{Comparative Analysis of Freshwater and Marine Viromes}

Clustering using UPGMA (unweighted pair group method with arithmetic mean, Figure 5a) and NMDS (non-metric multidimensional scaling; Figure 5b-d) based on the similarities and differences of assembled virome reads (scaffolds) identified three groups of samples. All samples from Lake Baikal were included in the first group, the second consisted of the samples of marine sponges, and the third group was a virome of ocean water from the sampling site of the I. basta sponges. Thus, the distances between marine samples (sponges and surrounding water) turned out to be much greater than between the Baikal samples (Figure 5a). The distribution of biplots also showed significant distances between samples of freshwater and marine sponges. The differences in viromes were clearly traced in mainly different directions of vectors of large taxonomic groups of viruses (families of virotypes) (Figure 5b), their predicted hosts (Figure 5c), and metabolic functions of viral communities in the samples (Figure $5 d$ ).

We compared the taxonomy of virotypes identified in metagenomic data from Baikal and marine (GBR) samples. The Myoviridae, Poxviridae, Ackermannviridae, and Mimiviridae generally predominated in GBR samples, especially in the I. basta sponges (Supplementary Table S1). Also noteworthy is the higher content of the Microviridae viruses (especially in plankton-6.4\%) and the Phycodnaviridae viruses $(2.7 \%$ to $7.2 \%)$ in marine samples (Supplementary Table S1). The Siphoviridae, Podoviridae, Lavidaviridae, and Baculoviridae, on the contrary, reliably prevailed in the Baikal samples. In general, the composition and proportions of the dominant families in the samples of water and sponges differed, as well as differing between the healthy and diseased sponges in the marine ecosystem, in contrast with the Baikal one. 
(a) Cluster dendrogram with p-values (\%)
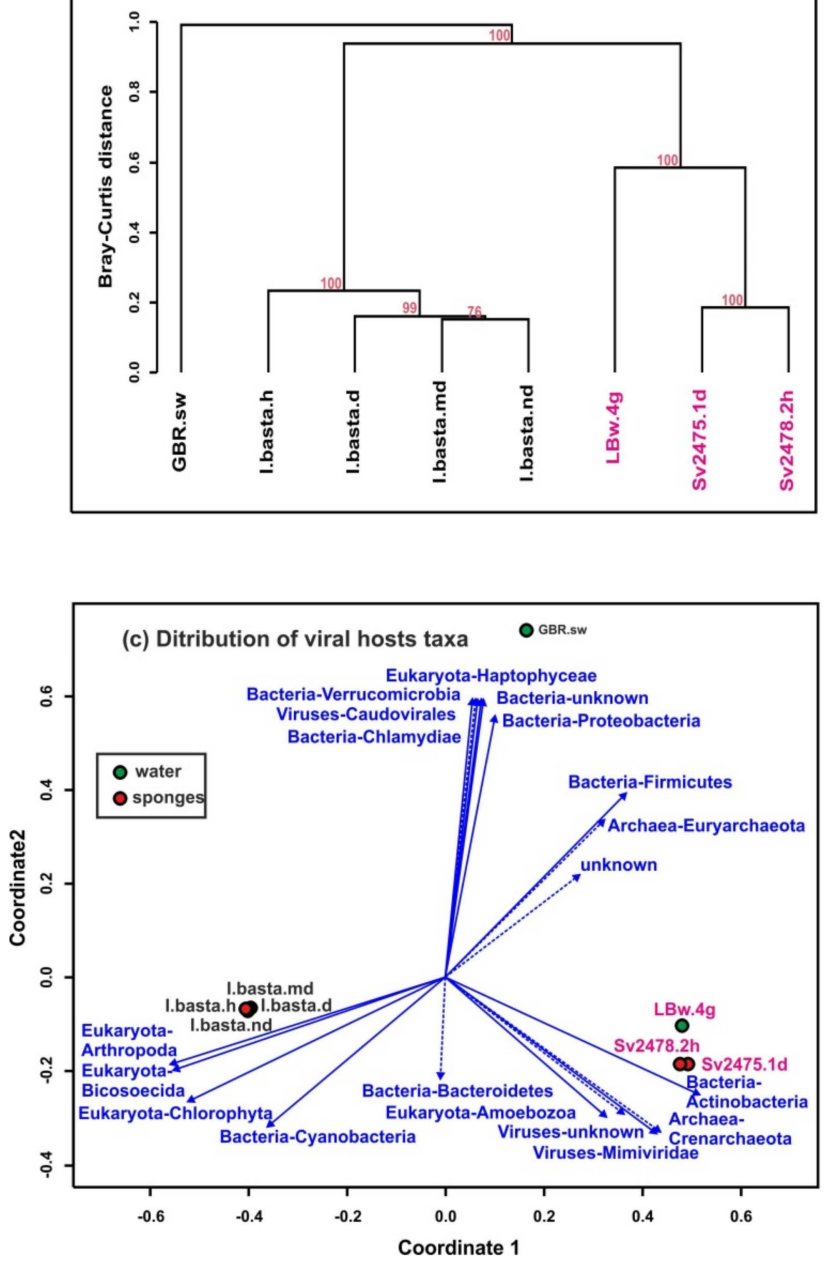

(b) Distribution of viral families

O GBR.sw
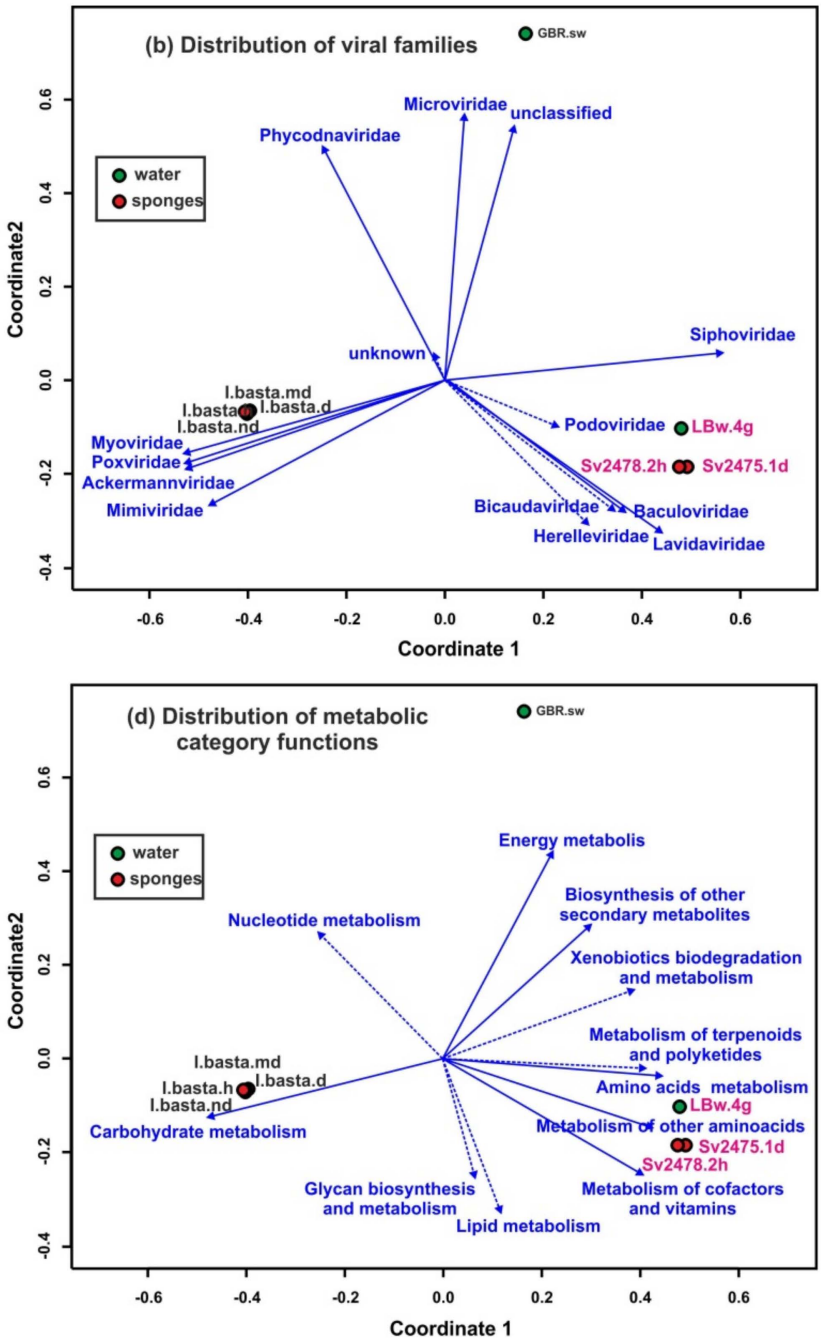

Figure 5. Clustering of samples by similarity of the representation of scaffolds identified as viral. (a) Dendrogram constructed by the "average" method based on the Bray-Curtis distances (the dendrogram nodes contain the bootstrap support values). (b-d) Non-metric multidimensional scaling (NMDS) biplots of the virome datasets showing the following: (b) identification of viral taxa by homology with viral genomes and proteomes from NCBI RefSeq (vectors indicate the viral families); (c) viral hosts prediction, carried out using the Virus-Host database; (d) analysis of metabolic functional categories of viral proteins (AMGs). Unreliable vectors are marked with a dotted line. The Baikal samples are highlighted in pink.

The list of dominant virotypes for marine and Baikal samples mostly did not overlap (Supplementary Figure S2 and Table S6). For example, the cyanophages dominating in marine viromes (Prochlorococcus phage P-TIM68, Synechococcus phage S-WAM2, Synechococcus phage S-CAM22, and others) were minor in the Baikal samples, and they were mainly represented by the Myoviridae family, in contrast with the Baikal ones, where cyanophages of the families Siphoviridae and Podoviridae were also present. The algae viruses Ostreococcus lucimarinus virus 7 and Ostreococcus tauri virus 1 were also among the most numerous virotypes in marine sponges, and the Emiliania huxleyi virus 86 predominated in seawater. All of them also had low representation in the Baikal samples. Despite the obvious differences between marine and freshwater sponge samples, we also identified a number of common scaffolds/virotypes, such as the dominant Cellulophaga phages (phi38:1, phi10:1, and phi19:3), some Synechococcus phages (S-SKS1 and others), Yellowstone lake phycodnaviruses 1 and 2, and others, as well as a number of unidentified sequences (Supplementary Table S6). 
In marine samples, as well as in Baikal ones, bacteria of the phyla Bacteroidetes and Arthropoda (insects) prevailed as the hosts in the sponge samples, while the Proteobacteria Actinobacteria, Firmicutes, and archaea Euryarchaeota predominated in the water sample (Supplementary Table S3). In contrast with the Baikal samples, cyanobacteria prevailed in the I. basta sponges (but not in seawater). The number of Proteobacteria in diseased and healthy sponges remained almost the same. Furthermore, in the list of hosts of marine viruses, we identified the bacteria Chlamydiae (microviruses), widespread ocean unicellular Haptophyceae algae (Emiliania huxleyi), and Escherichia virus P2 (the Myoviridae family) that helps for the lytic growth of satellite Enterobacteria P4 (infects E. coli and other Enterobacteriaceae).

The functional profiles of all the samples of the $I$. basta sponge were similar. A significant difference was observed only in the 'Cell growth and death' category-namely, an increase in proteins of this group in the healthy sponge specimen (Figure 3). The profile of the control seawater sample was very different from the distribution of proteins in the $I$. basta sponges, as in the case of the Baikal samples. Incidentally, the enzymes of replication and repair predominated in sea water, as well as in fresh water; however, in general, we did not observe correlations in the distribution of functional categories and in the differences between the samples of sponges and surrounding waters in freshwater and marine ecosystems (Figure 3; Supplementary Table S8).

\section{Discussion}

\subsection{Analysis of the Reads Assembly of Marine and Freshwater Virome Samples}

In this study, we examined the diversity of the DNA viral communities in two individuals of the Baikal endemic sponges, Baikalospongia bacillifera (tentatively healthy and damaged with necrotic lesions) [25], by assembling metagenomic reads and describing the viral scaffolds and predicted proteins. For comparative analysis, we selected from the NCBI SRA database a similar set of virome data from non-diseased and diseased (with unspecified syndrome) marine sponges, Ianthella basta, sampled from the Great Barrier Reef [22], as well as of the water sample from the sponge sampling site (Table 1).

To analyze the virome data on Baikal and non-Baikal samples (Table 1), as well as in our previous study of viruses from aquatic communities [45], we applied the approach of the de novo cross-assembly of metagenomic reads. All original virome reads were combined into one sample (all left reads into one sample of left reads, all right reads into one sample of right reads). Thereafter, the resulting set of right and left reads was used for the cross-assembly and identification of viral scaffolds. This approach has an advantage over assembling each sample separately because it allows the comparison of viromes of different samples without direct linking of the resulting scaffolds to the taxonomy of viruses. By mapping the initial reads of each metagenomic sample to the resulting scaffolds, we estimated the representation of each scaffold in the sample, thereby, obtaining a table of quantitative data for direct analysis using computational methods of environmental research. The cross-assembly enabled us to correctly use the scaffolds that were not identified as virotype for the comparative analysis of samples. Another advantage of cross-assembly is the ability to assemble longer virus scaffolds with an increased dataset owing to the presence of genetic material of the same or closely related virus species in different samples. A disadvantage of this cross-assembly approach is the need to use a supercomputer with a very large amount of RAM (1 TB or more) to process a large k-mer array required to construct a De Bruijn graph in the genomic data assembly algorithm [70].

Of the total data, about $23 \%$ of the scaffolds were identified as viral, and most of these scaffolds (about 76\%) were similar to the fragments of genomes or proteomes from the NCBI RefSeq viral database. The largest number of assembled viral sequences had low similarity with known viral genomes (considering genome-scaffold coverage, number of similar proteins, and sequence similarity). Most of the viral sequences had genome coverage within $10 \%$ to $20 \%$, rarely more than $40 \%$. From $5 \%$ to $19 \%$ of the original metagenomic reads mapped to scaffolds were identified as viral (Table 2). Thus, most of 
the genomic reads were unidentified, and most predicted protein-coding genes had no similarities with protein motifs from the databases used for the analysis. Such results are typical for virome studies; in other analyses of viral communities in aquatic [45,71-74] and other environments [75,76], including those associated with marine sponges [15], the percentage of viral reads was even lower (a few percent).

\subsection{The Diversity of Viral Communities in the B. bacillifera}

In Baikal virome datasets, the identified viral scaffolds were similar to 11 families of DNA-containing viruses. The highest numbers of virotypes belonged to the families of bacteriophages (Siphoviridae, Myoviridae, Podoviridae, and others). This is expectable because the abundance of bacteria accounts for up to $35 \%$ of the total sponge biomass, and their densities exceed $10^{9}$ cells per cubic centimeter of sponge [77]. A study [20] assumed that tailed VLPs may be more abundant on the external surface of the sponges. We also identified the viral families that are known to infect microalgae (Phycodnaviridae), archaea (Bicaudaviridae), protozoa (Mimiviridae and Lavidaviridae), and invertebrates (Baculoviridae and Poxviridae). These families, except for the Lavidaviridae, were found earlier in the viromes of marine sponges $[14,16]$. A large abundance of virophage sequences was discovered previously in the viromes of Baikal water [45].

The greatest similarity of viral scaffolds (based on the similarity percentage and the number of matching proteins) was found with cyanophages, as well as with some viruses that infect Proteobacteria: Idiomarinaceae phage 1N2-2, Pseudomonas phage PA11, and Bordetella virus BPP1. Perhaps, the related viruses, like their hosts, have a wide range of habitats (sea and fresh waters, soils, wetlands, and others). For instance, bacteria of the family Idiomarinaceae (Gammaproteobacteria) were isolated from saline habitats [78]. The bacteria Pseudomonas sp. are present in all habitats, but some species such as P. aeruginosa tend to be present in areas closely associated with human activities [79]. Representatives of the genus Pseudomonas and their viruses were isolated previously from Lake Baikal [80,81]. For eukaryotic viruses, there was the greatest overlap of scaffolds with Yellowstone Lake virophage 5 and Melanoplus sanguinipes entomopoxvirus also isolated from the geographically distant and distinctive environments [82,83].

\subsection{Comparative Analysis of Viromes of Diseased and Healthy B. bacillifera and the Surrounding Baikal Water}

A comparative analysis of the diseased and the visually healthy sponges revealed a greater number of virotypes in a healthy sponge (183 vs. 163). This difference in diversity is most likely associated with a decrease in the total number of associated microorganisms in the necrotic sponge. We determined the same composition but different percentages of viral families in diseased and healthy sponges (Figure 2a; Table 3; Supplementary Table S1). For example, the abundance of Myoviridae phages (larger number in a diseased sponge) and viruses of algae Phycodnaviridae (on the contrary, larger number in a healthy one) varied significantly. The dominant virotypes in the two sponges also differed (Figure $2 b$; Table 3; Supplementary Table S2). The diversity shift in the sponge-associated microbial communities in the unhealthy individuals was reported previously, but different changes were found in analyzed diseased specimens, and no patterns were revealed [35-40,84,85]. During the experimental thermal stress, the viral compositions of the Rhopaloiedes odorabile sponges from the Great Barrier Reef also changed; this, for example, led to the loss of ssDNA viruses [86].

The comparison of the viromes of the sponges and the control water sample revealed even more significant differences in the composition of viral families, especially, of virotypes (Supplementary Tables S1 and S2; Figure 2a,b). The most significant difference was the much higher abundance of scaffolds similar to picocyanobacterial viruses in the water sample and the high content of viral sequences related to Cellulophaga phages in the $B$. bacillifera sponges. Our previous study of the Baikal endemic sponges Lubomirskia baikalensis based on marker phage genes g20 also supported the specific viral communities within 
sponge holobionts [87]. The specificity of sponge viral communities was also shown in the studies of marine sponges [14,22].

We assessed the functional potential and metabolic genes of the viral communities of Baikal sponges and revealed differences in the functional profiles of healthy and diseased individuals as well as in sponges and surrounding water (Figures 3 and 4). In the diseased $B$. bacillifera sponges, functional genes associated with amino acid metabolism increased. Perhaps, this is due to the active recovery processes taking place in the damaged (with lesions of necrosis in this case) sponges. According to our observations, Baikal sponges can heal the affected areas: on some apparently healthy $B$. bacillifera sponges with an intact surface, a violation of the globular structure and large notches were observed during diving and sampling. Moreover, in the viral communities of diseased sponges, the number of genes for biosynthesis of folate and glycans and other metabolic functions (except for 'amino acid metabolism') was reduced in the diseased sponge compared with the healthy one (Figure 3; Supplementary Table S8). This may be due to a decrease in the taxonomic diversity of viruses in diseased sponges. As a consequence, the important functions that are characteristic of the normal functioning of the sponge holobiont are lost during dysbiosis. Under the conditions of a short-term experiment, the authors [86] did not observe the changes in the functional set of viral genes. However, our data indicate that under natural conditions, with prolonged stress or disease, the shift in the taxonomic composition and metabolic profiles occurs not only in microbial [37-40,88-90] but also in viral sponge-associated communities. Most likely, the recorded changes depend on various factors, and only a more targeted analysis of a large number of sponge samples can yield more accurate conclusions.

Our results reveal the significant differences in the functional potential of viral communities and in the sets of viral metabolic (AMG) genes in the sponges and plankton of Lake Baikal. Thus, the functional analysis also confirmed the nonrandom diversity (i.e., specificity) and the functional role of the viral communities in sponge holobionts.

\subsection{Putative Viral Hosts for Baikal Viruses}

The taxonomic groups of potential bacterial hosts of identified virotypes in the Baikal samples were the Bacteroidetes, Actinobacteria, Proteobacteria, Cyanobacteria, Firmicutes, and Verrucomicrobia (Figures 2c and 5c; Supplementary Tables S3 and S7). These bacterial phyla are known components of sponge microbiomes $[3,77]$. They were also identified in different Baikal sponges (L. baikalensis, Baikalospongia intermedia, and Swartschewskia papyracea) [37-40,88,89] and in water column of Lake Baikal [91,92] during previous studies. Representatives of the Bacteroidetes and Actinobacteria (the main groups of predicted viral hosts) are well-known biomass destructors in a wide spectrum of niches, including freshwater [93]. Actinobacteria dominate in microbial community of Lake Baikal, particularly in the coastal zone (from 32\% to 69\% sequences in the 16S rRNA gene analysis) [90]. In healthy sponges, the Actinobacteria varied over a wide range (from 3.5\% to 14\%) [88,89]; however, in damaged specimens of L. baikalensis, their proportion reached only $8.6 \%$, and their diversity shifted towards the benthic- and soil-derived representatives of the phylum [90].

Recently, the various bacterial strains (35 bacterial ones) belonging to the phyla Actinobacteria, Firmicutes, Bacteroidetes, and Proteobacteria were isolated from symbiotic community of sponge L. baikalensis [64,94]; a potential ability of many cultured microorganisms from different taxonomic groups to produce secondary metabolites was also shown [94]. As is known, these specialized compounds are not required for normal cell growth, but they may play an important ecological role in the interactions with surrounding organisms or the environment. We found the multiple viral genes for the synthesis of antimicrobial and other auxiliary metabolites in Baikal sponges. Thus, due to the AMGs, viruses can stimulate the vital activity and increase the competitiveness or communication of bacterial hosts, thereby maintaining the functioning of the entire holobiont, especially under unfavorable conditions and during disease (dysbiosis).

On the other hand, the bacteria are forced to defend themselves against viral infections; there are various defense mechanisms: CRISPR-Cas, restriction-modification (RM), and 
other systems. In the study of microbial communities of sponge holobionts from deep-sea hydrothermal vents [95], the multiple genes related to diverse anti-phage defense systems (RM, CRISPR-Cas, toxin-antitoxin, and others) were found. We tested the recently published genomes of the bacteria Janthinobacterium sp. SLB01 (refers to Proteobacteria) and Flavobacterium sp. SLB02 (Bacteroidetes) isolated from diseased L. baikalensis sponges [95] and also revealed the presence of various defense systems in them, including CRISPR-Cas; moreover, the matches were found when comparing revealed CRISPR-Cas spacers and virus scaffolds from the sponges B. bacillifera (Supplementary Tables S4 and S5, Files S3 and S4).

A new approach (phage fluorescence in situ hybridization-correlative light and electron microscopy, PhageFISH-CLEM) discovered that the phagocytosis of viral particles by sponge cells modulates phage-bacteria ratios and ultimately controls viral infections in Mediterranean sponges. Such tripartite interplay (animal-phage-bacterium) led to dominance of lysogeny the sponge microbiome, while lysis predominates in seawater [96]. However, in our study, the integrases, as temperate phage markers, were revealed mainly in scaffolds from Baikal and GBR waters. In deep-sea hydrothermal vent sponges (in the southern Okinawa Trough), the prophages were also rarely found in the genomes of bacterial symbionts [95], which may indicate distinct phage replication strategies in different sponges or environments.

The Baikal sponges are known to be a host for symbiotic green microalgae [97]. The presence of the Chlorophyta in the range of putative hosts in the samples of $B$. bacillifera (especially in the 'healthy' one) (Figure 5c; Supplementary Table S3) may be associated with these symbionts previously revealed in the Baikal sponges. As shown, the Chlorophyta gradually disappears in 'diseased' samples $[39,40]$ similar to our data. We also notice the presence of the Amoebozoa, which has been poorly studied for the most part in sponge associations. Sponges are inhabited by many other invertebrate species (crustaceans, mollusks, etc.) [98]; this can explain the presence of viruses (virotypes) of the Arthropoda in our data.

\subsection{Comparative Analysis of Marine and Freshwater Viromes}

We also compared the Baikal viromes with similar NCBI SRA datasets (diseased and healthy sponges; sponge and control water samples) from marine sponges Ianthella basta, analyzed using the same sample preparation and sequencing methods as in our study. This allowed us to reduce the possible shifts associated with the methodological procedure and increase the chance of a more objective comparison of viral communities of different sponge species.

The number of identified viral scaffolds and virotypes in the viromes of the $I$. basta sponges was lower than in B. bacillifera (190 to 225 vs. 404 to 417 scaffolds and 89 to 109 vs. 168 to 171 virotypes), despite a much higher number of reads for the $I$. basta sponges (Table 2). In GBR and Baikal waters, it also slightly differed (384 and 428 scaffolds, 178 and 183 virotypes, respectively). It is important to note that the microbial composition of other freshwater sponges (Eunapius carteri, Corvospongilla lapidosa, and Tubella variabilis) was also more diverse in comparison with the marine sponge microbiota $[99,100]$.

As in the case of Baikal sponges, the number of scaffolds/virotypes in a healthy sponge was greater than in a diseased one. Our analysis revealed that the taxonomic composition of viral communities (at the level of viral families or virotypes), putative hosts, and predicted functional viral genes of marine samples was very different from freshwater samples (Figures 3-5). The similarities were observed in the general composition of viral families, some virotypes, and dominant host taxa. The identified common virotypes may indicate the presence of closely related sponge-specific viruses as well as bacterial hosts in marine and freshwater sponges. Interestingly, the shifts in the taxonomic and functional profiles of viral communities in diseased sponges compared with healthy ones are more obvious in Baikal sponges than in marine ones (Figure 5a). Perhaps, this is due to the different degree or duration of damage between GBR and Baikal sponges. 
Despite the high content of unicellular algae in Baikal sponges, which gives them a green color [97], and in the lake plankton, viruses of the Phycodnaviridae, like other large viruses of the families Poxviridae and Mimiviridae, were scarce in the Baikal viromes, and their content in the Baikal samples was much lower than in the marine ones. First, the number of bacteriophages presumably really exceeds the abundance of other viruses in Baikal sponges and lake plankton. Second, this pool of viruses may be lost during sample preparation (for example, during centrifugation or filtration, Supplementary File S1). On the other hand, freshwater phycodnaviruses are poorly studied (Baikal phycodnaviruses have not been studied at all), and our list of virotypes contains only the marine Phycodnaviridae viruses.

The other significant difference between Baikal and GBR sponges was a much higher abundance of picocyanophage virotypes in the I. basta sponges (Supplementary Figure S2). Cyanophages are most studied in aquatic ecosystems in comparison with other bacteriophages. In spite of this, most of the scaffolds affiliated with cyanophages had low similarity rates, indicating a great diversity and insufficient knowledge about them as well as other bacteriophages in nature. In our study, the cyanophages most similar to the Baikal viral scaffolds (mostly covered by the Baikal virome reads) had a much lower similarity with the sequences from marine samples and vice versa (Supplementary Table S6 and Figure S2). Such differences were found for many other virotypes, which also indicates a difference in viral communities concerning the composition of analyzed marine and freshwater sponges.

Revealed differences between the freshwater and marine samples can be explained by many factors; the largest and most obvious of them are the difference in sponge species, contrasting habitat (marine and freshwater), and climatic conditions, as well as geographical distance. All of these factors entail a difference in the species composition of the associated sponge community, including viruses; however, it was shown during a global comparison of the microbiota of different sponges that the main structure-forming factor may be the sponge environment (marine or freshwater) [100]. Notably, the unique and extreme conditions of the Baikal ecosystem determine the presence of a large number of endemic species of flora and fauna, including the B. bacillifera sponges [101], which also severely affects the formation of microbial communities in Baikal water and sponges.

\section{Conclusions}

This study revealed the high genetic, taxonomic, and functional diversity of the DNA viruses in Baikal endemic sponges B. bacillifera. We also identified differences in the composition of viral communities in healthy and diseased sponges, as well as obtaining a large set of viral sequences that did not have similarities with the genomes of known viruses from the NCBI database. Considering that we and other researchers carried out special sample preparation to isolate VLPs and viral genetic material, we can assume that some of the viral sequences belong to unknown viruses that do not have close relatives in the NCBI RefSeq viral database. Since sponge viruses are practically unknown [102], a certain part of the identified or unidentified viral sequences very likely belongs to viruses that infect not only microorganisms associated with sponges but also sponges themselves. We hope that in the future, with the intensive replenishment of international databases with genomic information on the studied viruses, the proportion of viral genetic material identified during the metagenomic analysis will increase. Perhaps the expansion of the databases of protein motifs will also allow for a more informative study of the functional ability of viral communities. A large number of unidentified proteins may belong to AMGs that play an important role in the interaction between the viruses and the hosts at the level of the populations and communities.

Supplementary Materials: The following are available online at https: / www.mdpi.com/article/ 10.3390/microorganisms10020480/s1, Figure S1: The percentage of the reads affiliated to Viruses, Bacteria, Archaea, and Eukaryota, Figure S2: Heat maps demonstrating the number of reads for dominant virotypes in samples from marine and freshwater ecosystems: (a) Representation of dominant virotypes in marine vs. freshwater samples, and, conversely; (b) representation of dominant virotypes in freshwater vs. marine samples, Table S1: The percentage of viral families in samples of 
marine and freshwater sponges and in water samples, Table S2: Viral scaffolds mostly represented in the Baikal samples by the number of reads and closely related viruses (virotypes); the maximum and average similarity (in \%) of predicted viral proteins with the NCBI RefSeq database (the ten largest sets of reads corresponding to specific scaffolds and virotype in each sample are marked in bold), Table S3: The percentage of putative host taxa predicted for viruses in samples, Table S4: The antiviral defense systems revealed in assembled genomes of Janthinobacterium sp. SLB01 and Flavobacterium sp. SLB02 isolated from the Baikal sponge Lubomirskia baikalensis (diseased), Table S5: Matches revealed between CRISPR-Cas spacers from bacterial strains of Janthinobacterium sp. Strain SLB01, and Flavobacterium sp. Strain SLB02 (isolated from the Baikal sponge Lubomirskia baikalensis, [66]) and viral scaffolds from the sponge Baikalospongia bacillifera, Table S6: Taxonomic identification of the viral scaffolds, the similarity of detected ORFs and RefSeq proteins, and the number of virome reads per scaffold, Table S7: The potential hosts for revealed viral scaffolds, identified using the Virus-Host database, and the number of virome reads per scaffold, Table S8: Main and secondary KO (KEGG Orthology) functional categories of predicted viral proteins and the number of reads related to these functions in marine and freshwater samples. All the information is available in Supplementary File S1-S4.

Author Contributions: Conceptualization, methodology, funding acquisition, writing—original draft preparation, T.V.B. and Y.S.B.; formal analysis, software, validation, visualization, Y.S.B. and I.S.P.; data curation, T.V.B. and Y.S.B.; organization of the expedition and sampling, I.V.K.; writing-review and editing, T.V.B., Y.S.B., I.S.P. and I.V.K.; project administration, T.V.B. and Y.S.B. All authors have read and agreed to the published version of the manuscript.

Funding: This research was carried out within the framework of the Siberian Branch of the Russian Academy of Sciences basic budget funding numbers 0279-2021-0005 and 0279-2021-0011 and funded by the Russian Foundation for Basic Research grant number 17-44-388080.

Institutional Review Board Statement: Not applicable.

Informed Consent Statement: Not applicable.

Data Availability Statement: Unprocessed virome reads for the samples of B. bacillifera Sv2475.1d, Sv2478.2h, and the Baikal water Lbw.4g were submitted to the National Center for Biotechnology Information (NCBI), Sequence Read Archive (SRA) database (BioProject PRJNA577390, BioSamples SAMN13025046, SAMN13025227, and SAMN16330433) [25,43]. The direct URL to the data is as follows: https:/ / www.ncbi.nlm.nih.gov/sra/PRJNA577390 (accessed on 20 December 2021).

Acknowledgments: We would like to thank The Center of Shared Scientific Equipment "Persistence of Microorganisms" of the Institute for Cellular and Intracellular Symbiosis UB RAS for carrying out metagenomic sequencing. The authors are grateful to the Irkutsk Supercomputer Center SB RAS for providing the access to HPC-cluster "Akademik V.M. Matrosov". We also thank Ivan Sidorov, a system administrator of HPC-cluster, for help in performing computations. The authors are grateful to the Bioinformatics Shared Access Center (Novosibirsk, Russia) for providing computational resources to perform calculations (assembly of paired reads). We would like to thank the staff of the Irkutsk Institute of Chemistry SB RAS, Yana Kostyro and Anna Soldatenko, for providing access to the equipment for tangential flow filtration (Sartocon Slice filtration system).

Conflicts of Interest: The authors declare no conflict of interest.

\section{References}

1. Hooper, J.N.A.; Van Soest, R.W.M. Systema Porifera. A Guide to the Classification of Sponges. In Systema Porifera; Springer: Boston, MA, USA, 2002; pp. 1-7.

2. Wulff, J. Ecological Interactions and the Distribution, Abundance, and Diversity of Sponges. Adv. Mar. Biol. 2012, 61, 273-344. [PubMed]

3. Webster, N.S.; Taylor, M.W. Marine sponges and their microbial symbionts: Love and other relationships. Environ. Microbiol. 2012, 14, 335-346. [CrossRef]

4. Loxdale, H.D.; Wilmer, P. Invertebrate Relationships: Patterns in Animal Evolution. J. Anim. Ecol. 1991, 60, 375-376. [CrossRef]

5. Diaz, M.C.; Rützler, K. Sponges: An essential component of Caribbean coral reefs. Bull. Mar. Sci. 2001, 69, 535-546.

6. Bell, J.J. The functional roles of marine sponges. Estuar. Coast. Shelf Sci. 2008, 79, 341-353. [CrossRef]

7. Kumar, S.M.; Pal, K.A. A review of bioactive compounds from marine organisms with special mention on the potential of marine sponges in pharmacological applications. J. Mar. Biol. Assoc. India 2016, 58, 84. [CrossRef] 
8. Steinert, G.; Stauffer, C.H.; Aas-Valleriani, N.; Borchert, E.; Bhushan, A.; Campbell, A.; De Mares, M.C.; Costa, M.; Gutleben, J.; Knobloch, S.; et al. BluePharmTrain: Biology and Biotechnology of Marine Sponges. In Grand Challenges in Biology and Biotechnology; Springer: Cham, Switzerland, 2018; pp. 505-553.

9. Manconi, R.; Pronzato, R. Phylum Porifera. In Thorp and Covich's Freshwater Invertebrates; Elsevier: Amsterdam, The Netherlands, 2019; pp. 43-92.

10. Itskovich, V.B.; Kaluzhnaya, O.V.; Veynberg, E.; Erpenbeck, D. Endemic Lake Baikal sponges from deep water. 2: Taxonomy and Bathymetric Distribution. Zootaxa 2017, 4236, 335-342. [CrossRef]

11. Bukshuk, N.A.; Maikova, O.O. A new species of baikal endemic sponges (Porifera, demospongiae, spongillida, lubomirskiidae). Zookeys 2020, 2020, 113-130. [CrossRef]

12. Khanaev, I.V.; Kravtsova, L.S.; Maikova, O.O.; Bukshuk, N.A.; Sakirko, M.V.; Kulakova, N.V.; Butina, T.V.; Nebesnykh, I.A.; Belikov, S.I. Current state of the sponge fauna (Porifera: Lubomirskiidae) of Lake Baikal: Sponge disease and the problem of conservation of diversity. J. Great Lakes Res. 2018, 44, 77-85. [CrossRef]

13. Dutilh, B.E.; Varsani, A.; Tong, Y.; Simmonds, P.; Sabanadzovic, S.; Rubino, L.; Roux, S.; Muñoz, A.R.; Lood, C.; Lefkowitz, E.J.; et al. Perspective on taxonomic classification of uncultivated viruses. Curr. Opin. Virol. 2021, 51, 207-215. [CrossRef]

14. Pascelli, C.; Laffy, P.W.; Botté, E.; Kupresanin, M.; Rattei, T.; Lurgi, M.; Ravasi, T.; Webster, N.S. Viral ecogenomics across the Porifera. Microbiome 2020, 8, 1-22. [CrossRef] [PubMed]

15. Nguyen, M.; Wemheuer, B.; Laffy, P.W.; Webster, N.S.; Thomas, T. Taxonomic, functional and expression analysis of viral communities associated with marine sponges. PeerJ 2021, 9, e10715. [CrossRef] [PubMed]

16. Ambalavanan, L.; Iehata, S.; Fletcher, R.; Stevens, E.H.; Zainathan, S.C. A review of marine viruses in coral ecosystem. J. Mar. Sci. Eng. 2021, 9, 711. [CrossRef]

17. Vacelet, J.; Gallissian, M.F. Virus-like particles in cells of the sponge Verongia cavernicola (demospongiae, dictyoceratida) and accompanying tissues changes. J. Invertebr. Pathol. 1978, 31, 246-254. [CrossRef]

18. Johnson, P.T. Viral diseases of marine invertebrates. Helgoländer Meeresunters. 1984, 37, 65-98. [CrossRef]

19. Claverie, J.M.; Grzela, R.; Lartigue, A.; Bernadac, A.; Nitsche, S.; Vacelet, J.; Ogata, H.; Abergel, C. Mimivirus and Mimiviridae: Giant viruses with an increasing number of potential hosts, including corals and sponges. J. Invertebr. Pathol. 2009, 101, 172-180. [CrossRef]

20. Pascelli, C.; Laffy, P.W.; Kupresanin, M.; Ravasi, T.; Webster, N.S. Morphological characterization of virus-like particles in coral reef sponges. Peer] 2018, 6, e5625. [CrossRef]

21. Laffy, P.W.; Wood-Charlson, E.M.; Turaev, D.; Weynberg, K.D.; Botté, E.S.; Van Oppen, M.J.H.; Webster, N.S.; Rattei, T. HoloVir: A workflow for investigating the diversity and function of viruses in invertebrate holobionts. Front. Microbiol. 2016, 7, 822. [CrossRef]

22. Laffy, P.W.; Wood-Charlson, E.M.; Turaev, D.; Jutz, S.; Pascelli, C.; Botté, E.S.; Bell, S.C.; Peirce, T.E.; Weynberg, K.D.; van Oppen, M.J.H.; et al. Reef invertebrate viromics: Diversity, host specificity and functional capacity. Environ. Microbiol. 2018, 20, 2125-2141. [CrossRef]

23. Batista, D.; Costa, R.; Carvalho, A.P.; Batista, W.R.; Rua, C.P.J.; de Oliveira, L.; Leomil, L.; Fróes, A.M.; Thompson, F.L.; Coutinho, R.; et al. Environmental conditions affect activity and associated microorganisms of marine sponges. Mar. Environ. Res. 2018, 142, 59-68. [CrossRef]

24. Butina, T.V.; Bukin, Y.S.; Khanaev, I.V.; Kravtsova, L.S.; Maikova, O.O.; Tupikin, A.E.; Kabilov, M.R.; Belikov, S.I. Metagenomic analysis of viral communities in diseased Baikal sponge Lubomirskia baikalensis. Limnol. Freshw. Biol. 2019, 155-162. [CrossRef]

25. Butina, T.V.; Khanaev, I.V.; Kravtsova, L.S.; Maikova, O.O.; Bukin, Y.S. Metavirome datasets from two endemic Baikal sponges Baikalospongia bacillifera. Data Br. 2020, 29, 105260. [CrossRef] [PubMed]

26. Waldron, F.M.; Stone, G.N.; Obbard, D.J. Metagenomic sequencing suggests a diversity of RNA interference-like responses to viruses across multicellular eukaryotes. PLoS Genet. 2018, 14, e1007533. [CrossRef] [PubMed]

27. Urayama, S.I.; Takaki, Y.; Hagiwara, D.; Nunoura, T. DsRNA-seq reveals novel RNA virus and virus-like putative complete genome sequences from hymeniacidon sp. Sponge. Microbes Environ. 2020, 35, ME19132. [CrossRef] [PubMed]

28. Harrington, C.; Del Casale, A.; Kennedy, J.; Neve, H.; Picton, B.E.; Mooij, M.J.; O’Gara, F.; Kulakov, L.A.; Larkin, M.J.; Dobson, A.D.W. Evidence of bacteriophage-mediated horizontal transfer of bacterial 16S rRNA genes in the viral metagenome of the marine sponge Hymeniacidon perlevis. Microbiology 2012, 158, 2789-2795. [CrossRef]

29. Kravtsova, L.S.; Izhboldina, L.A.; Khanaev, I.V.; Pomazkina, G.V.; Domysheva, V.M.; Kravchenko, O.S.; Grachev, M.A. Disturbances of the vertical zoning of green algae in the coastal part of the Listvennichnyi gulf of Lake Baikal. Dokl. Biol. Sci. 2012, 447, 350-352. [CrossRef]

30. Kravtsova, L.S.; Izhboldina, L.A.; Khanaev, I.V.; Pomazkina, G.V.; Rodionova, E.V.; Domysheva, V.M.; Sakirko, M.V.; Tomberg, I.V.; Kostornova, T.Y.; Kravchenko, O.S.; et al. Nearshore benthic blooms of filamentous green algae in Lake Baikal. J. Great Lakes Res. 2014, 40, 441-448. [CrossRef]

31. Timoshkin, O.A.; Samsonov, D.P.; Yamamuro, M.; Moore, M.V.; Belykh, O.I.; Malnik, V.V.; Sakirko, M.V.; Shirokaya, A.A.; Bondarenko, N.A.; Domysheva, V.M.; et al. Rapid ecological change in the coastal zone of Lake Baikal (East Siberia): Is the site of the world's greatest freshwater biodiversity in danger? J. Great Lakes Res. 2016, 42, 487-497. [CrossRef]

32. Bondarenko, N.A.; Logacheva, N.F. Structural changes in phytoplankton of the littoral zone of Lake Baikal. Hydrobiol. J. 2017, 53, 16-24. [CrossRef] 
33. Webster, N.S. Sponge disease: A global threat? Environ. Microbiol. 2007, 9, 1363-1375. [CrossRef]

34. Luter, H.M.; Webster, N.S. Sponge Disease and Climate Change. In Climate Change, Ocean Acidification and Sponges; Springer: Cham, Switzerland, 2017; pp. 411-428.

35. Pita, L.; Rix, L.; Slaby, B.M.; Franke, A.; Hentschel, U. The sponge holobiont in a changing ocean: From microbes to ecosystems. Microbiome 2018, 6, 46. [CrossRef] [PubMed]

36. Luter, H.M.; Bannister, R.J.; Whalan, S.; Kutti, T.; Pineda, M.-C.; Webster, N.S. Microbiome analysis of a disease affecting the deep-sea sponge Geodia barretti. FEMS Microbiol. Ecol. 2017, 93, 74. [CrossRef] [PubMed]

37. Denikina, N.N.; Dzyuba, E.V.; Bel'kova, N.L.; Khanaev, I.V.; Feranchuk, S.I.; Makarov, M.M.; Granin, N.G.; Belikov, S.I. The first case of disease of the sponge Lubomirskia baicalensis: Investigation of its microbiome. Biol. Bull. 2016, 43, 263-270. [CrossRef]

38. Kulakova, N.V.; Sakirko, M.V.; Adelshin, R.V.; Khanaev, I.V.; Nebesnykh, I.A.; Pérez, T. Brown Rot Syndrome and Changes in the Bacterial Community of the Baikal Sponge Lubomirskia baicalensis. Microb. Ecol. 2018, 75, 1024-1034. [CrossRef] [PubMed]

39. Belikov, S.; Belkova, N.; Butina, T.; Chernogor, L.; Van Kley, A.M.; Nalian, A.; Rorex, C.; Khanaev, I.; Maikova, O.; Feranchuk, S. Diversity and shifts of the bacterial community associated with Baikal sponge mass mortalities. PLoS ONE 2019, 14, e0213926. [CrossRef]

40. Itskovich, V.; Kaluzhnaya, O.; Glyzina, O.; Prathiviraj, R.; Kiran, G.S.; Selvin, J. Microbiome Changes of Endemic Lake Baikal Sponges during Bleaching Syndrome Development. Diversity 2021, 13, 653. [CrossRef]

41. Choudhury, J.D.; Pramanik, A.; Webster, N.S.; Llewellyn, L.E.; Gachhui, R.; Mukherjee, J. The Pathogen of the Great Barrier Reef Sponge Rhopaloeides odorabile Is a New Strain of Pseudoalteromonas agarivorans Containing Abundant and Diverse VirulenceRelated Genes. Mar. Biotechnol. 2015, 17, 463-478. [CrossRef]

42. Fan, L.; Reynolds, D.; Liu, M.; Stark, M.; Kjelleberg, S.; Webster, N.S.; Thomas, T. Functional equivalence and evolutionary convergence in complex communities of microbial sponge symbionts. Proc. Natl. Acad. Sci. USA 2012, 109, E1878-E1887. [CrossRef]

43. Butina, T.V.; Petrushin, I.S.; Khanaev, I.V.; Bukin, Y.S. Virome Analysis of Near-Bottom Coastal Water of Lake Baikal. Microbiol. Resour. Announc. 2020, 9, 1-3. [CrossRef]

44. Bolger, A.M.; Lohse, M.; Usadel, B. Trimmomatic: A flexible trimmer for Illumina sequence data. Bioinformatics 2014, 30, 2114-2120. [CrossRef]

45. Butina, T.V.; Bukin, Y.S.; Petrushin, I.S.; Tupikin, A.E.; Kabilov, M.R.; Belikov, S.I. Extended evaluation of viral diversity in lake baikal through metagenomics. Microorganisms 2021, 9, 760. [CrossRef] [PubMed]

46. Nurk, S.; Meleshko, D.; Korobeynikov, A.; Pevzner, P.A. MetaSPAdes: A new versatile metagenomic assembler. Genome Res. 2017, 27, 824-834. [CrossRef] [PubMed]

47. Roux, S.; Enault, F.; Hurwitz, B.L.; Sullivan, M.B. VirSorter: Mining viral signal from microbial genomic data. PeerJ 2015,3 , e985. [CrossRef] [PubMed]

48. Pruitt, K.D.; Tatusova, T.; Maglott, D.R. NCBI Reference Sequence (RefSeq): A curated non-redundant sequence database of genomes, transcripts and proteins. Nucleic Acids Res. 2005, 33, D501-D504. [CrossRef]

49. Altschul, S.F.; Gish, W.; Miller, W.; Myers, E.W.; Lipman, D.J. Basic local alignment search tool. J. Mol. Biol. 1990, $215,403-410$. [CrossRef]

50. Li, H.; Durbin, R. Fast and accurate short read alignment with Burrows-Wheeler transform. Bioinformatics 2009, 25, 1754-1760. [CrossRef]

51. O'Hara, R.B. Species richness estimators: How many species can dance on the head of a pin? J. Anim. Ecol. 2005, 74, 375-386. [CrossRef]

52. Colwell, R.K.; Coddington, J.A. Estimating terrestrial biodiversity through extrapolation. Biodivers. Meas. Estim. 1995, 345, 101-118.

53. Hill, M.O. Diversity and Evenness: A Unifying Notation and Its Consequences. Ecology 1973, 54, 427-432. [CrossRef]

54. Suzuki, R.; Shimodaira, H. Pvclust: An R package for assessing the uncertainty in hierarchical clustering. Bioinformatics 2006, 22, 1540-1542. [CrossRef]

55. Oksanen, J. Vegan: Ecological Diversity. 2018. Available online: https://cran.r-project.org/web/packages/vegan/vignettes/ diversity-vegan.pdf (accessed on 20 December 2021).

56. Warnes, G.R.; Bolker, B.; Bonebakker, L.; Gentleman, R.; Liaw, W.H.A.; Lumley, T.; Maechler, M.; Magnusson, A.; Moeller, S.; Schwartz, M.; et al. Package "gplots": Various R Programming Tools for Plotting Data; R Package Version 2.17.0; ScienceOpen: Berlin, Germany, 2015; pp. 1-68.

57. Bairoch, A.; Apweiler, R.; Wu, C.H.; Barker, W.C.; Boeckmann, B.; Ferro, S.; Gasteiger, E.; Huang, H.; Lopez, R.; Magrane, M.; et al. The Universal Protein Resource (UniProt). Nucleic Acids Res. 2005, 33, D154-D159. [CrossRef] [PubMed]

58. Mistry, J.; Chuguransky, S.; Williams, L.; Qureshi, M.; Salazar, G.A.; Sonnhammer, E.L.L.; Tosatto, S.C.E.; Paladin, L.; Raj, S.; Richardson, L.J.; et al. Pfam: The protein families database in 2021. Nucleic Acids Res. 2021, 49, D412-D419. [CrossRef] [PubMed]

59. Madeira, F.; Park, Y.M.; Lee, J.; Buso, N.; Gur, T.; Madhusoodanan, N.; Basutkar, P.; Tivey, A.R.N.; Potter, S.C.; Finn, R.D.; et al The EMBL-EBI search and sequence analysis tools APIs in 2019. Nucleic Acids Res. 2019, 47, W636-W641. [CrossRef]

60. Aramaki, T.; Blanc-Mathieu, R.; Endo, H.; Ohkubo, K.; Kanehisa, M.; Goto, S.; Ogata, H. KofamKOALA: KEGG Ortholog assignment based on profile HMM and adaptive score threshold. Bioinformatics 2020, 36, 2251-2252. [CrossRef] [PubMed] 
61. Mao, X.; Cai, T.; Olyarchuk, J.G.; Wei, L. Automated genome annotation and pathway identification using the KEGG Orthology (KO) as a controlled vocabulary. Bioinformatics 2005, 21, 3787-3793. [CrossRef] [PubMed]

62. Tenenbaum, D. KEGGREST: Client-Side REST Access to KEGG. R Package Version 1.28.0. 2020. Available online: http:// bioconductor.org/packages/release/bioc/html/KEGGREST.html (accessed on 20 December 2021).

63. Mihara, T.; Nishimura, Y.; Shimizu, Y.; Nishiyama, H.; Yoshikawa, G.; Uehara, H.; Hingamp, P.; Goto, S.; Ogata, H. Linking virus genomes with host taxonomy. Viruses 2016, 8, 66. [CrossRef]

64. Petrushin, I.; Belikov, S.; Chernogor, L. Cooperative interaction of janthinobacterium sp. Slb01 and flavobacterium sp. slb02 in the diseased sponge lubomirskia baicalensis. Int. J. Mol. Sci. 2020, 21, 8128. [CrossRef]

65. Payne, L.J.; Todeschini, T.C.; Wu, Y.; Perry, B.J.; Ronson, C.W.; Fineran, P.C.; Nobrega, F.L.; Jackson, S.A. Identification and classification of antiviral defence systems in bacteria and archaea with PADLOC reveals new system types. Nucleic Acids Res. 2021, 49, 10868-10878. [CrossRef]

66. Couvin, D.; Bernheim, A.; Toffano-Nioche, C.; Touchon, M.; Michalik, J.; Néron, B.; Rocha, E.P.C.; Vergnaud, G.; Gautheret, D.; Pourcel, C. CRISPRCasFinder, an update of CRISRFinder, includes a portable version, enhanced performance and integrates search for Cas proteins. Nucleic Acids Res. 2018, 46, W246-W251. [CrossRef]

67. Edwards, R.A.; McNair, K.; Faust, K.; Raes, J.; Dutilh, B.E. Computational approaches to predict bacteriophage-host relationships. FEMS Microbiol. Rev. 2016, 40, 258-272. [CrossRef]

68. La Scola, B.; Desnues, C.; Pagnier, I.; Robert, C.; Barrassi, L.; Fournous, G.; Merchat, M.; Suzan-Monti, M.; Forterre, P.; Koonin, E.; et al. The virophage as a unique parasite of the giant mimivirus. Nature 2008, 455, 100-104. [CrossRef] [PubMed]

69. Doron, S.; Melamed, S.; Ofir, G.; Leavitt, A.; Lopatina, A.; Keren, M.; Amitai, G.; Sorek, R. Systematic discovery of antiphage defense systems in the microbial pangenome. Science 2018, 359, eaar4120. [CrossRef] [PubMed]

70. Compeau, P.E.C.; Pevzner, P.A.; Tesler, G. How to apply de Bruijn graphs to genome assembly. Nat. Biotechnol. 2011, 29, 987-991. [CrossRef]

71. Breitbart, M.; Salamon, P.; Andresen, B.; Mahaffy, J.M.; Segall, A.M.; Mead, D.; Azam, F.; Rohwer, F. Genomic analysis of uncultured marine viral communities. Proc. Natl. Acad. Sci. USA 2002, 99, 14250-14255. [CrossRef] [PubMed]

72. De Cárcer, D.A.; López-Bueno, A.; Alonso-Lobo, J.M.; Quesada, A.; Alcamí, A. Metagenomic analysis of lacustrine viral diversity along a latitudinal transect of the Antarctic Peninsula. FEMS Microbiol. Ecol. 2016, 92, 1-10. [CrossRef] [PubMed]

73. Butina, T.V.; Bukin, Y.S.; Krasnopeev, A.S.; Belykh, O.I.; Tupikin, A.E.; Kabilov, M.R.; Sakirko, V.; Belikov, S.I. Estimate of the diversity of viral and bacterial assemblage in the coastal water of Lake Baikal. FEMS Microbiol. Lett. 2019, 366, fnz094. [CrossRef] [PubMed]

74. Potapov, S.A.; Tikhonova, I.V.; Krasnopeev, A.Y.; Kabilov, M.R.; Tupikin, A.E.; Chebunina, N.S.; Zhuchenko, N.A.; Belykh, O.I. Metagenomic analysis of virioplankton from the pelagic zone of Lake Baikal. Viruses 2019, 11, 991. [CrossRef]

75. Park, E.-J.; Kim, K.-H.; Abell, G.C.J.; Kim, M.-S.; Roh, S.W.; Bae, J.-W. Metagenomic Analysis of the Viral Communities in Fermented Foods. Appl. Environ. Microbiol. 2011, 77, 1284-1291. [CrossRef]

76. Santos-Medellin, C.; Zinke, L.A.; ter Horst, A.M.; Gelardi, D.L.; Parikh, S.J.; Emerson, J.B. Viromes outperform total metagenomes in revealing the spatiotemporal patterns of agricultural soil viral communities. ISME J. 2021, 15, 1956-1970. [CrossRef]

77. Hentschel, U.; Piel, J.; Degnan, S.M.; Taylor, M.W. Genomic insights into the marine sponge microbiome. Nat. Rev. Microbiol. 2012, 10, 641-654. [CrossRef]

78. Albuquerque, L.; da Costa, M.S. The Family Idiomarinaceae. In The Prokaryotes; Rosenberg, E., DeLong, E.F., Lory, S., Stackebrandt, E., Thompson, F., Eds.; Springer: Berlin/Heidelberg, Germany, 2014; pp. 361-385.

79. Crone, S.; Vives-Flórez, M.; Kvich, L.; Saunders, A.M.; Malone, M.; Nicolaisen, M.H.; Martínez-García, E.; Rojas-Acosta, C.; Catalina Gomez-Puerto, M.; Calum, H.; et al. The environmental occurrence of Pseudomonas aeruginosa. Apmis 2020, 128, $220-231$. [CrossRef] [PubMed]

80. Evseev, P.; Sykilinda, N.; Gorshkova, A.; Kurochkina, L.; Ziganshin, R.; Drucker, V.; Miroshnikov, K. Pseudomonas Phage PaBG-A Jumbo Member of an Old Parasite Family. Viruses 2020, 12, 721. [CrossRef]

81. Evseev, P.V.; Gorshkova, A.S.; Sykilinda, N.N.; Drucker, V.V.; Miroshnikov, K.A. Pseudomonas bacteriophage AN14 a Baikal-borne representative of Yuavirus. Limnol. Freshw. Biol. 2020, 5, 1055-1066. [CrossRef]

82. Zhou, J.; Sun, D.; Childers, A.; McDermott, T.R.; Wang, Y.; Liles, M.R. Three Novel Virophage Genomes Discovered from Yellowstone Lake Metagenomes. J. Virol. 2015, 89, 1278-1285. [CrossRef]

83. Afonso, C.L.; Tulman, E.R.; Lu, Z.; Oma, E.; Kutish, G.F.; Rock, D.L. The Genome of Melanoplus sanguinipes Entomopoxvirus. J. Virol. 1999, 73, 533-552. [CrossRef] [PubMed]

84. Gao, Z.M.; Wang, Y.; Tian, R.M.; Lee, O.O.; Wong, Y.H.; Batang, Z.B.; Al-Suwailem, A.; Lafi, F.F.; Bajic, V.B.; Qian, P.Y. Pyrosequencing revealed shifts of prokaryotic communities between healthy and disease-like tissues of the Red Sea sponge Crella cyathophora. PeerJ 2015, 3, e890. [CrossRef]

85. Blanquer, A.; Uriz, M.J.; Cebrian, E.; Galand, P.E. Snapshot of a bacterial microbiome shift during the early symptoms of a massive sponge die-offin the western Mediterranean. Front. Microbiol. 2016, 7, 1-10. [CrossRef]

86. Laffy, P.W.; Botté, E.S.; Wood-Charlson, E.M.; Weynberg, K.D.; Rattei, T.; Webster, N.S. Thermal stress modifies the marine sponge virome. Environ. Microbiol. Rep. 2019, 11, 690-698. [CrossRef] [PubMed]

87. Butina, T.V.; Potapov, S.A.; Belykh, O.I.; Belikov, S.I. Genetic diversity of cyanophages of the myoviridae family as a constituent of the associated community of the Baikal sponge Lubomirskia baicalensis. Russ. J. Genet. 2015, 51, 313-317. [CrossRef] 
88. Gladkikh, A.S.; Kalyuzhnaya, O.V.; Belykh, O.I.; Ahn, T.S.; Parfenova, V.V. Analysis of bacterial communities of two Lake Baikal endemic sponge species. Microbiology 2014, 83, 787-797. [CrossRef]

89. Seo, E.Y.; Jung, D.; Belykh, O.I.; Bukshuk, N.A.; Parfenova, V.V.; Joung, Y.; Kim, I.C.; Yim, J.H.; Ahn, T.S. Comparison of bacterial diversity and species composition in three endemic Baikalian sponges. Ann. Limnol. 2016, 52, 27-32. [CrossRef]

90. Lipko, I.; Krasnopeev, A.; Tikhonova, I.; Timoshkin, O.; Kabilov, M.; Belykh, O. Genetic diversity of Actinobacteria inhabiting water and sponges of Lake Baikal. Limnol. Freshw. Biol. 2020, 4, 998-999. [CrossRef]

91. Bukin, Y.S.; Galachyants, Y.P.; Morozov, I.V.; Bukin, S.V.; Zakharenko, A.S.; Zemskaya, T.I. The effect of 16s rRNA region choice on bacterial community metabarcoding results. Sci. Data 2019, 6, 190007. [CrossRef] [PubMed]

92. Coutinho, F.H.; Cabello-Yeves, P.J.; Gonzalez-Serrano, R.; Rosselli, R.; López-Pérez, M.; Zemskaya, T.I.; Zakharenko, A.S.; Ivanov, V.G.; Rodriguez-Valera, F. New viral biogeochemical roles revealed through metagenomic analysis of Lake Baikal. Microbiome 2020, 8, 163. [CrossRef]

93. Newton, R.J.; Jones, S.E.; Eiler, A.; McMahon, K.D.; Bertilsson, S. A Guide to the Natural History of Freshwater Lake Bacteria. Microbiol. Mol. Biol. Rev. 2011, 75, 14-49. [CrossRef] [PubMed]

94. Kaluzhnaya, O.V.; Lipko, I.A.; Itskovich, V.B. PCR-screening of bacterial strains isolated from the microbiome of the Lubomirskia baicalensis sponge for the presence of secondary metabolite synthesis genes. Limnol. Freshw. Biol. 2021, 2021, 1137-1142. [CrossRef]

95. Zhou, K.; Qian, P.Y.; Zhang, T.; Xu, Y.; Zhang, R. Unique phage-bacterium interplay in sponge holobionts from the southern Okinawa Trough hydrothermal vent. Environ. Microbiol. Rep. 2021, 13, 675-683. [CrossRef]

96. Jahn, M.T.; Lachnit, T.; Markert, S.M.; Stigloher, C.; Pita, L.; Ribes, M.; Dutilh, B.E.; Hentschel, U. Lifestyle of sponge symbiont phages by host prediction and correlative microscopy. ISME J. 2021, 15, 2001-2011. [CrossRef]

97. Rezvoi, P.D. The Fauna of the USSR. Freshwater Sponges; AS USSR: Moscow, Russia, 1936.

98. Kamaltynov, R.M.; Chernykh, V.I.; Slugina, Z.V.; Karabanov, E.B. The consortium of the sponge Lubomirskia baicalensis in Lake Baikal, East Siberia. Hydrobiologia 1993, 271, 179-189. [CrossRef]

99. Gaikwad, S.; Shouche, Y.S.; Gade, W.N. Microbial community structure of two freshwater sponges using Illumina MiSeq sequencing revealed high microbial diversity. Amb Express 2016, 6, 40. [CrossRef]

100. Laport, M.S.; Pinheiro, U.; Rachid, C.T.C.D.C. Freshwater sponge Tubella variabilis presents richer microbiota than marine sponge species. Front. Microbiol. 2019, 10, 2799. [CrossRef] [PubMed]

101. Kozhova, O.M.; Izmesteva, L.R. Lake Baikal: Evolution and Biodiversity; Backhuys Publisher: Leiden, The Netherlands, 1998.

102. Williams, T.; Bergoin, M.; van Oers, M.M. Diversity of large DNA viruses of invertebrates. J. Invertebr. Pathol. 2017, 147, 4-22. [CrossRef] [PubMed] 